\title{
Impact of Aldosterone on the Failing Myocardium: Insights from Mitochondria and Adrenergic Receptors Signaling and Function
}

\author{
Mariona Guitart-Mampel ${ }^{1,+} \mathbb{D}$, Pedro Urquiza ${ }^{1,+}$, Jordana I. Borges ${ }^{2}$, Anastasios Lymperopoulos ${ }^{2, *(D)}$ \\ and Maria E. Solesio ${ }^{1, * \mathbb{D}}$ \\ 1 Department of Biology, College of Arts and Sciences, Rutgers University, Camden, NJ 08103, USA; \\ mg1616@camden.rutgers.edu (M.G.-M.); pu23@camden.rutgers.edu (P.U.) \\ 2 Department of Pharmaceutical Sciences, College of Pharmacy, Nova Southeastern University, \\ Fort Lauderdale, FL 33328, USA; jb3837@mynsu.nova.edu \\ * Correspondence: al806@nova.edu (A.L.); m.solesio@rutgers.edu (M.E.S.) \\ + These authors have contributed equally and they are listed in alphabetical order.
}

check for updates

Citation: Guitart-Mampel, M.;

Urquiza, P.; Borges, J.I.;

Lymperopoulos, A.; Solesio, M.E.

Impact of Aldosterone on the Failing

Myocardium: Insights from

Mitochondria and Adrenergic

Receptors Signaling and Function.

Cells 2021, 10, 1552. https://doi.org/

10.3390/cells10061552

Academic Editor: András Balla

Received: 28 April 2021

Accepted: 16 June 2021

Published: 19 June 2021

Publisher's Note: MDPI stays neutral with regard to jurisdictional claims in published maps and institutional affiliations.

\begin{abstract}
AbstractThe mineralocorticoid aldosterone regulates electrolyte and blood volume homeostasis, but it also adversely modulates the structure and function of the chronically failing heart, through its elevated production in chronic human post-myocardial infarction (MI) heart failure (HF). By activating the mineralocorticoid receptor (MR), a ligand-regulated transcription factor, aldosterone promotes inflammation and fibrosis of the heart, while increasing oxidative stress, ultimately induding mitochondrial dysfunction in the failing myocardium. To reduce morbidity and mortality in advanced stage HF, MR antagonist drugs, such as spironolactone and eplerenone, are used. In addition to the MR, aldosterone can bind and stimulate other receptors, such as the plasma membraneresiding $G$ protein-coupled estrogen receptor (GPER), further complicating it signaling properties in the myocardium. Given the salient role that adrenergic receptor (ARs)—particularly $\beta$ ARs_-play in cardiac physiology and pathology, unsurprisingly, that part of the impact of aldosterone on the failing heart is mediated by its effects on the signaling and function of these receptors. Aldosterone can significantly precipitate the well-documented derangement of cardiac AR signaling and impairment of AR function, critically underlying chronic human HF. One of the main consequences of HF in mammalian models at the cellular level is the presence of mitochondrial dysfunction. As such, preventing mitochondrial dysfunction could be a valid pharmacological target in this condition. This review summarizes the current experimental evidence for this aldosterone/AR crosstalk in both the healthy and failing heart, and the impact of mitochondrial dysfunction in HF. Recent findings from signaling studies focusing on MR and AR crosstalk via non-conventional signaling of molecules that normally terminate the signaling of ARs in the heart, i.e., the G protein-coupled receptor-kinases (GRKs), are also highlighted.
\end{abstract}

Keywords: adverse remodeling; aldosterone; signaling crosstalk; G protein-coupled receptor (GPCR); heart failure; mineralocorticoid receptor; mitochondria; mitochondrial dysfunction; mitochondrial dynamics; mitochondrial bioenergetics

\section{Introduction}

Heart failure (HF) is a major health concern worldwide, affecting $10 \%$ of the adult population [1]. A complex syndrome, it is defined by damaged contractile performance of the myocardium, leading the heart to undersupply blood to the peripheral tissues [1]. The mineralocorticoid aldosterone plays a key role in this pathology [2]. Specifically, aldosterone regulates electrolyte homeostasis and blood pressure and volume. It also modulates cardiac adverse remodeling post-myocardial infarction (MI) via direct effects on the myocardium. Therefore, aldosterone antagonists, such as spironolactone and eplerenone, 
reduce morbidity and mortality in human HF and are part of the cornerstone pharmacotherapy of advanced stage disease [3]. Aldosterone has multiple effects in cardiac myocytes, fibroblasts, coronary endothelial cells, and infiltrating immune cells (e.g., macrophages), including its direct involvement in the dysregulation of cardiac adrenergic receptors (ARs), which mediate the effects of norepinephrine (NE) and epinephrine (Epi) on the heart. The ARs comprise nine different subtypes in mammals: $\alpha 1 \mathrm{~A}, \alpha 1 \mathrm{~B}, \alpha 1 \mathrm{D}, \alpha 2 \mathrm{~A}, \alpha 2 \mathrm{~B}, \alpha 2 \mathrm{C}, \beta 1, \beta 2$, and $\beta 3$. All nine are class-A G protein-coupled receptors (GPCRs), and most play pivotal roles in regulating cardiac function, physiology, and pathophysiology [2]. Moreover, a major molecular hallmark of human chronic $\mathrm{HF}$ is the dysfunction/dysregulation of $\beta \mathrm{AR}$ signaling, leading to diminished inotropic and adrenergic reserves of the failing heart. Consequently, the myocardium no longer properly responds to NE or Epi, i.e., by increasing its contractile function [2,4-6]. This marks the "point of no return" for the heart, upon which cardiac function no longer operates on the Frank-Starling curve of cardiac elasticity; instead, it operates under the Laplace's law of increased filling pressure, proportionally increasing the free ventricular wall pressure, ultimately causing cardiac hypertrophy, dilatation, and other remodeling processes culminating in reduced ejection fraction and cardiac output, i.e., in systolic HF [2].

At the cellular level, mitochondrial dysfunction has been described as a crucial component of the etiopathology of multiple diseases [7-14], including cardiac dysfunction induced by elevated aldosterone [15]. Moreover, it is known that aldosterone increases the production of reactive oxygen species (ROS), via NADPH oxidase [16,17]. Consequently, increased oxidative stress, cardiac mitochondrial dysfunction, and accelerated cardiac aging have been described in different mammalian models of HF [18-20]. Specifically, this increased ROS production induces in the organelle a loss of metabolic capacity, including dysregulated dynamics and bioenergetics. At the molecular level, the effects of aldosterone in mitochondria are mediated by the down regulator of the A-kinase anchor protein (AKAP)-12, a protein which has a mineralocorticoid receptor (MR) [21]. Furthermore, another crucial contributor towards the progression of systolic HF is the impaired production of high energy phosphates [18].

Since both mitochondrial and AR dysfunction in the heart are pathological hallmarks of the detrimental actions of aldosterone in $\mathrm{HF}$, the present review focuses on the impact of aldosterone on these two key parameters regulating cardiac function. We first summarize the current experimental evidence for the cardiac mitochondrial dysfunction underlying $\mathrm{HF}$, followed by an overview of the cardiac AR dysregulation underlying chronic HF. We then present the evidence on the role that aldosterone plays in the impairment of both mitochondrial and AR signaling and function in the myocardium, leading to, and/or accelerating, the development of chronic HF. Also highlighted are some of the latest findings on the crosstalk between aldosterone, mitochondria, and cardiac AR signaling with novel therapeutic repercussions for human HF treatment.

\section{Aldosterone and Mitochondrial Dysfunction in the Failing Heart}

A set of highly complex and interconnected cellular and molecular mechanisms underlies HF [22,23], some of these mechanisms are closely related to mitochondria, as in the case of biogenesis and turnover of the organelle, and ATP production [23]. Moreover, the preservation of mitochondrial physiology is crucial for cell survival, especially in nondividing cells with high demands of energy, such as cardiomyocytes [24]. In these cells, mitochondrial dysfunction has been linked to increased apoptosis, ultimately leading to cardiomyopathy, one of the major causes of HF $[24,25]$. The explanation for this may be that almost $90 \%$ of the energy demands of the heart are met by the mitochondrial oxidative phosphorylation (OXPHOS), which is the major source of ATP in mammals [26]. ATP synthesis is paired with cell respiration and oxygen consumption in the electron transport chain (ETC), composed of four complexes (I, II, III and IV), that ATP synthase, and two mobile electron carriers (coenzyme $Q$ and cytochrome C) [27]. As a result of OXPHOS, mitochondria are also the leading source of ROS generation within mammalian cells. In 
these cells, ROS are the main contributors to increased oxidative stress, under pathological conditions [28]. Interestingly, ROS are closely related to high energy phosphates in mitochondrial, as they are both produced during OXPHOS. One important source of high energy phosphate inside mitochondria is inorganic polyphosphate (polyP) [29-31,31]. In fact, the involvement of polyP on heart physiology, has been already demonstrated in cardiac myocytes [32-34].

Some studies have shown the deleterious effects of a high-fat diet (HFD) widely associated with $\mathrm{HF}$, on mitochondrial function in the myocardium of male rats [35]. These rats showed abnormal expression of genes and proteins involved on mitochondrial dynamics; decreased number of copies of mitochondrial DNA; reduced enzymatic activities of ETC complexes I, II and III and citrate synthase- the key enzyme in the Krebs cycle; as well as decreased mitochondrial respiration and ATP levels. These data were corroborated by another study, conducted in a rabbit model of $\mathrm{HF}$, using proteomics techniques, the authors showed altered levels of the main proteins involved in the cellular energy metabolism, including pyruvate dehydrogenase and mitochondrial ATP synthase [36]. Furthermore, in diabetic murine hearts (type 2), decreased levels of inner mitochondrial membrane proteins involved in bioenergetics processes, ATP synthesis, and mitochondrial protein import system; were found [37]. Type 2 diabetes is associated with reduced lifespan in humans, due to increased prevalence of HF [37]. Additionally, using left ventricular tissue obtained from HF patients undergoing heart transplantation, reduced mitochondrial oxygen respiration and reduced activity of ETC complexes and of citrate synthase were reported [38].

In another research article, upregulation of certain genes in HF patients was highlighted. Specifically, the authors found that the genes related to mitochondrial ATP synthase were those most affected. Downregulation of genes related to autophagy was also present in the same samples [39]. Finally, in another study, the presence of mitochondrial enzymatic defects in left ventricular tissue obtained from human HF patients was examined. The authors concluded that, compared with non-failing donor hearts, the activity rates of complexes I and IV, as well as of Krebs cycle enzymes such as malate dehydrogenase, were decreased in HF patients [40].

As mentioned above, the deleterious presence of increased oxidative stress, a classical consequence of dysregulated OXPHOS, has already been broadly demonstrated in the etiopathology of cardiac remodeling, the main process responsible for the development and progression of HF [25]. Corroborating these findings, different authors showed that activation of the mitochondrial detoxifying systems, which are involved in preventing and/or decreasing oxidative stress, is a valid strategy to prevent cardiac degeneration in HF [41-46]. Diverse preclinical and clinical studies have shown the protective effects of several mitochondrial-targeted molecules against HF [47-51]. Similarly, other authors analyzed the effects of MitoQ, a mitochondrial-addressed antioxidant [9], on the development and progression of HF induced by pressure overload. This study concluded that MitoQ restored mitochondrial membrane potential, crucial for the proper functioning and OXPHOS, and thus, of mitochondrial respiration [42].

Mitochondrial dynamics (fission and fusion) and mitophagy, all processes closely related to bioenergetics, have been also proved to be dysfunctional in HF [52]. Mitochondrial fission and fusion are in a tight equilibrium, and they are essential contributors towards maintaining healthy mitochondria by efficiently mixing mitochondrial components to compensate for any defects present in mitochondrial DNA (fusion), and by increasing the number of new mitochondria when energy demand is also increased (fission process) $[53,54]$. Fission also allows damaged regions of mitochondrion to be removed by mitophagy. While fission events are mediated by dynamin-related protein 1 (Drp1), which is recruited to mitochondria by MFF (Mitochondrial Fission Factor) and promotes fission thanks to its GTPase activity; mitofusin 1 and 2 (Mfn1 and Mfn2), two proteins located on the outer mitochondrial membrane, and optic atrophy 1 protein (OPA1), located in the inner mitochondrial membrane, are governing the fusion process [54]. As stated above, mitophagy, a mitochondrial-specific type of autophagy, is activated when defective mito- 
chondria are present in cells, usually after dysfunctional fission. In this process, damaged mitochondria are surrounded by double membrane vesicles that fuse with lysosomes to eliminate the organelles $[54,55]$.

Some studies have described dysfunctional dynamics and mitophagy in HF. For example, in a mouse model in which transverse aortic constriction (TAC) was performed to induce HF, increased mitophagy was observed around 3-7 days after TAC, as well as increasing mitochondrial translocation of Drp1. However, mitophagy was downregulated, followed by mitochondrial dysfunction [56]. Another study, also conducted using mice, showed that unbalanced OPA1 processing and mitochondrial fragmentation, often indicate signs of increased fission of the organelle, are critical in the etiopathology of HF [57]. In this work, the authors generated conditional mouse models for YmeL11 and OMA1 (two peptidases needed for appropriated OPA1 processing) finding that OPA1 proteolysis was accelerated, triggering increased mitochondrial fragmentation and altered cardiac metabolism. The authors concluded that appropriated adult myocardial function depends on balanced mitochondrial dynamics [57]. All of these studies show that proper mitochondrial physiology is key for adequate cardiac function, and that the impairment of mitochondrial physiology is considered pivotal in the progression of HF. Interestingly, this impairment could be at least partially mediated by aldosterone and MR. As mentioned above, the hormone aldosterone is one of the main volume-regulatory effectors. Consequently, it is vital for fluid and hemodynamic homeostasis in mammals, and it is a major regulator of blood pressure and heart rate in humans [43].

In the heart, one of the main effects of the binding of aldosterone to MR is the modulation of cardiac physiology through the interaction of the aldosterone-MR complex with the epidermal growth factor receptor (EGFR). Several studies show that the effect of aldosterone stimulates EGFR activation through its biding to MR, which ultimately regulates the renin/angiotensin/aldosterone system (RAAS) [46]. RAAS main physiological functions are to elevate blood volume and arterial tone by increasing sodium and water reabsorption and vascular tone [58-60]. Accordingly, dysregulated activation of RAAS can lead to the development of hypertension and chronically alter the blood volume, such as in renal artery stenosis [43,58,61].

Intracellularly, the stimulation of EGFR increases the production of ROS, via reduced NADPH oxidase and mitochondria [46,62]. Specifically, EGFR activates the NADPH oxidase (NOX), increasing the generation of the superoxide anion $\left(\mathrm{O}_{2}{ }^{-}\right) \cdot \mathrm{O}_{2}{ }^{-}$is then converted into hydrogen peroxide $\left(\mathrm{H}_{2} \mathrm{O}_{2}\right)$ by the superoxide dismutase enzyme (SOD). The subsequent production of $\mathrm{H}_{2} \mathrm{O}_{2}$ induces the opening of the mitochondrial ATP-dependent potassium channels (mitoKATP), yielding to enhanced mitochondrial $\mathrm{O}_{2}{ }^{-}$production by the ETC, on a deleterious cycle $[59,63]$. Intriguingly, $\mathrm{O}_{2}{ }^{-}, \mathrm{H}_{2} \mathrm{O}_{2}$ and other mitochondrial ROS have been described as potent signaling molecules [46]. In fact, a study conducted in obese mice models, showed that the activation of MRs increases cellular senescence and mitochondrial dysfunction in the adipocyte tissue, which consequently increases vascular contractility, leading to vascular dysfunction [64]. The study showed that the aldosterone-induced oxidative stress could be mediated by AKAPs. Indeed, AKAPs play a role in the modulation of ROS synthesis by their ability to bind to the regulatory subunit of cAMP-dependent protein kinase A (PKA) [65]. Specifically, aldosterone downregulates the expression of AKAP-1 in adult human cardiac fibroblasts, which leads to increased ROS, mitochondrial dysfunction, and ultimately apoptotic cell death $[21,66]$. Furthermore, the aldosterone-MR signaling pathway has also shown to affect mitochondrial function through the regulation of the adenylyl-cyclase, the enzyme that synthesizes cAMP $[67,68]$. cAMP activates PKA, which phosphorylates $\mathrm{Ca}^{2+}$ channels $[65,69,70]$. Consequently, both increased ROS release into the cytosol and phosphorylation of these channels, including the Mitochondrial Calcium Uniporter (MCU) channel ultimately turn into the enhancement of the intracellular calcium influx into the mitochondria, with deleterious effects for these organelles, and ultimately for the whole cell [71]. 
Based on the above bibliography, targeting mitochondria is a promising approach in HF. In fact, some hormones such as cortisol or aldosterone, which are the physiological pathway by which MRs typically are activated and/or modulated, can be pharmacologically modulated. Moreover, AR blockage could be another plausible pharmacological strategy against HF. There are pre-clinical studies in animals using (i) Propranolol, the study showed decreased respiratory control index in cardiac mitochondria [72]; (ii) Metoprolol, the study showed inhibition of the metabolism of fatty acids into the mitochondria $\beta$ oxidation, which optimizes cardiac bioenergetics, contributing to decreased decompensatory effects in HF [73]; (iii) Carvedilol, the study showed inhibition of the mitochondrial permeability transition pore opening, which decreases cell damage and increases mitochondria biogenesis [26]; and (iv) Atenolol, the study showed reduced mitochondria oxygen consumption and, consequently, ROS production [74]. However, the two only published clinical trials, which are randomized comparisons between the effects of MR blockers and placebo in patients with HF, reported no conclusive results $[75,76]$. Therefore, further research should be conducted in this field. Moreover, mitochondrial dysfunction in HF is closely interconnected with the effects induced by the failing hear in the rest of the cell. Therefore, understanding the extra-mitochondrial components of the etiopathology of HF, including the adrenergic system and the role of aldosterone, are crucial to search for new pharmacological targets in HF, both mitochondrial and non-mitochondrial.

\section{Cardiac Adrenergic Receptor Signaling and Dysregulation in HF}

The sympathetic nervous system (SNS) is a central actor in cardiovascular regulation. In fact, the heart receives dense noradrenergic innervation emanating from cervical and thoracic ganglia [77]. $\beta$-ARs belong to the G protein-coupled receptor (GPCR) superfamily, mediating many of the actions of norepinephrine (NE) on the heart, which is released from SNS neuronal store vesicles inside presynaptic neurons, and of epinephrine (Epi) activating these receptors via the blood circulation stemming from the adrenal medulla, where it is primarily synthesized and secreted [78]. Cardiomyocytes express various AR subtypes with the $\beta_{1}$ AR being the most predominant subtype under physiological conditions. Additionally, about $15 \%$ of the cardiac AR complement is the $\beta_{2} \mathrm{AR}$ subtype, and the rest is comprised of $\beta_{3} \mathrm{AR}$, which has negative inotropic properties, and $\alpha_{1} \mathrm{ARs}$ [79-81] $\beta_{1} A R s$ and $\beta_{2} A R s$ promote the classic effects of SNS on the heart, i.e., positive inotropy, chronotropy, lusitropy, and dromotropy via the stimulation of the stimulatory $\mathrm{G}$ protein alpha subunit $\left(G_{\mathrm{s} \alpha}\right)$, which directly activates membrane-bound adenylyl cyclase (AC) to convert adenosine trisphosphate (ATP) to cyclic $3^{\prime}, 5^{\prime}$-adenosine monophosphate (cAMP). cAMP is a major second messenger activating PKA, a protein which phosphorylates a variety of target proteins involved in calcium handling (excitation-contraction coupling) and in contractility regulation, such as L-type $\mathrm{Ca}^{2+}$ channels (LTCC's), sarcoplasmic reticulum (SR) $\mathrm{Ca}^{2+}$ release channels (ryanodine receptors), SR-residing $\mathrm{Ca}^{2+}$-ATPase (SERCA) activation via phospholamban phosphorylation, troponin-I, phospholemman, etc. [2,82]. Moreover, $\beta_{2}$ ARs also couples to pertussis toxin-sensitive inhibitory/other $G$ proteins $\left(G_{i / o}\right)$, resulting in negative inotropy but increased survival (anti-apoptosis) [83-85]. It is important to note that in cardiac cells that are not myocytes, i.e., fibroblasts, endothelial cells, immune cells, the predominant $\beta A R$ subtype is the $\beta_{2} A R$, not the $\beta_{1} A R$ [86].

In chronic HF with reduced ejection fraction, the chronically elevated SNS activity results in adverse cardiac remodeling and diminished inotropic and adrenergic reserves [86]. Increased SNS activity portends poor prognosis in HF patients [87-89]. Moreover, in animal models, chronic $\beta$-agonist administration leads to heart damage and remodeling marked by cardiomyocyte loss, leukocyte infiltration, interstitial fibrosis and dysfunction [90,91]. Of note, sympathomimetics such as dobutamine and PDE3 inhibitors (e.g., milrinone) have also failed in clinical trials of chronic HF due to increased cardiac apoptosis and oxygen/metabolic demand that the failing heart fails to meet [3]. Furthermore, studies conducted in transgenic mice overexpressing cardiac $\beta A R$ or downstream signaling molecules such as AC and PKA, also support the notion of enhanced cardiac toxicity exerted by the 
hyperactive SNS [92-94]. This has formed the basis for the initially extremely controversial clinical use of $\beta$-blockers in chronic HF patients. However, recent findings show that $\beta$-blockers, especially carvedilol, metoprolol, and bisoprolol, improve long-term prognosis in HF patients by counteracting the chronic toxicity of elevated catecholamines $[95,96]$.

Like most GPCRs, $\beta_{1}$ ARs and $\beta_{2}$ ARs undergo phosphorylation by GPCR-kinases (GRKs), followed by the switching of their coupling from $G$ proteins to $\beta$-arrestins. The latter consist of two isoforms, $\beta$-arrestin 1 and -2 , both of which are scaffold signaling proteins, thereby promoting non-G protein-dependent signaling [97]. There is evidence that aberrant $\beta A R$ signaling is a culprit for the molecular underpinnings of HF. In fact, transgenic mice overexpressing $\beta_{2}$ AR fail to develop HF if crossed with mice expressing a dominant-negative mutant $\mathrm{p} 38$ mitogen-activated protein kinase (MAPK) in their hearts, indicating that $\beta_{2}$ AR signaling through p38 MAPK leads to HF [98]. In contrast, $\beta$-arrestin ( $\beta$-arrestin2 in particular) signaling might be cardio-protective and pro-contractile in the post-infarct heart progressing to HF [99-104].

Interestingly, SNS hyperactivity leads to $\beta_{1} \mathrm{AR}$ downregulation (i.e., total functional receptor number reduced) in human failing hearts, accompanied by $\beta_{2} \mathrm{AR}$ increased desensitization, i.e., severe G-protein decoupling $[105,106]$. Indeed, elevated NE plasma levels correlate with significant loss of myocardial $\beta$ AR function/signaling in HF patients $[107,108] . \quad \beta_{1}$ AR downregulation occurs either via reduced receptor synthesis or post-translational modifications, as a result of agonist-induced desensitization which leads to $\beta$-arrestin- and clathrin-dependent receptor internalization and, ultimately, lysosomal degradation (downregulation). Alternatively, the receptor can recycle back to the plasma membrane ready to signal again upon subsequent agonist stimulation (resensitization) $[2,106]$. Whereas cardiac $\beta_{1}$ AR density is reduced in HF, $\beta_{2} \mathrm{AR}$ density remains the same, which means that the $\beta_{1} A R: \beta_{2} A R$ ratio becomes almost 50:50 in the failing human heart. Nevertheless, compartmentalization of $\beta_{2}$ AR signaling is fundamentally altered in $\mathrm{HF}$, which renders this subtype equally incapable of signaling and functioning properly, like its $\beta_{1} A R$ counterpart [2,109]. In addition, enhanced $\beta_{2} A R$ signaling through $\mathrm{G}_{\mathrm{i}}$ (rather than $\mathrm{G}_{\mathrm{s}}$ ) proteins further contributes to the reduced inotropic reserve of the failing heart, which is almost exclusively dependent on cAMP [110]. Interestingly, under physiological conditions, $\beta_{2} A R$ is cardio-protective via $G_{i}$ protein/phosphoinositide-3' kinase (PI3K) activation [111]. The most abundant GRK in the heart, GRK2, is further upregulated and opposes pro-contractile signaling of both $\beta_{1} \mathrm{AR}$ and $\beta_{2} \mathrm{AR}$ [112-115]. Moreover, $\beta_{2} \mathrm{AR}$ signaling is highly compartmentalized inside cardiomyocytes [116,117], and this subcellular targeting/anchoring of this receptor's signaling is lost in HF [116,118]. Indeed, $\beta_{2} \mathrm{AR}$ cAMP-mediated signaling is diffuse throughout the cardiac myocyte in failing hearts $[119,120]$.

Studies in transgenic mice have revealed that $\beta_{2} \mathrm{AR}$ cardiac-specific overexpression leads to age-dependent onset of HF, fibrosis, ventricular arrhythmias, and premature death $[116,117,121]$. Moreover, mice overexpressing $\beta_{2} \mathrm{AR}$ in their cardiomyocytes also display accelerated pressure overload-precipitated HF onset, and decreased survival with enhanced adverse remodeling of the heart [122]. Interestingly, during post-myocardial infarction (MI), these mice show preservation of cardiac function and less severe HF, indicating a beneficial role for cardiac $\beta_{2}$ AR post-MI [123]. Chronic administration of a high doses of $\beta A R$ agonists, such as isoproterenol or epinephrine, induces significant cardiac dysfunction, and $\beta_{2}$ AR stimulation preferentially activating $G_{i}$ protein-mediated contractility suppression in the apical more so than in the basal region of the myocardium [124].

Although PKA, the kinase activated by cAMP, has been exhaustively studied in the heart and assigned a plethora of $\beta A R$-elicited effects in the myocardium, the role of the other effector activated by cAMP, Epac (exchange protein directly activated by cAMP), which was initially discovered in 1998 [125], has been increasingly appreciated over the past two decades. Epac has two major isoforms, Epac1 and Epac2 [126]. The latter appears mainly expressed in neuronal tissues, while Epac1 is ubiquitously expressed and quite abundant in the heart [126]. Epac1 acts as a multi-protein complex forming scaffold 
molecule, pretty much like $\beta$-arrestins. It activates a variety of effectors, most importantly $\mathrm{Ca}^{2+} /$ calmodulin-dependent protein kinase (CaMKII) and the small (monomeric) G protein Rap1 [126]. Epac1 is abundant also in cardiac mitochondria, where it mediates cardiomyocyte apoptosis via $\mathrm{Ca}^{2+}$ overload and increases the mitochondrial permeability [127]. In fact, Epac1 promotes mitochondrial $\mathrm{Ca}^{2+}$ influx via VDAC1 (voltage-dependent anionselective channel-1) and MCU [128]. Since $\mathrm{Ca}^{2+}$ mitochondrial levels tightly regulate and closely related to cellular respiration and ATP biosynthesis [129], Epac1 plays an important role in regulation of energy consumption in the heart. In fact, Epac1 is also known to increase ROS generation, which ultimately leads to adverse cardiac remodeling and apoptosis [130]. Moreover, at the cellular level, cardiac Epac1 has been reported to be upregulated upon chronic catecholamine administration, upon TAC-induced pressure overload, and in end-stage HF patient-derived hearts [126]. In fact, Epac1 genetic deletion protects against cardiac hypertrophy, apoptosis, and fibrosis, in response to chronic catecholamine stimulation or pressure overload [131,132]. To further support the crucial role of this protein in heart physiology, Epac1 knockout as well as Epac1 pharmacological inhibition led to cardioprotective effects in animal models of stress-induced cardiomyopathy [133].

Interestingly, $\beta_{1} \mathrm{AR}$ has also been shown in heterologous systems in vitro to interact with $\mathrm{Gi} \alpha$ subunits of $\mathrm{G}$ proteins, similarly to its $\beta_{2} \mathrm{AR}$ counterpart, although this fact remains still highly controversial. For example, the $\beta$-blocker carvedilol was recently shown to induce a $\beta_{1}$ AR-Gi $\alpha$ interaction that supposedly facilitates subsequent $\beta$-arrestin signaling by this receptor [134]. Carvedilol has also been reported to promote $\beta_{1}$ AR-Gi $\alpha$ interaction that leads to signaling via the cardioprotective PI3K/Akt/nitric oxide (NO)/protein kinase G (PKG) pathway [135]. As previously mentioned, these findings are quite controversial, given that carvedilol is an inverse agonist for $\mathrm{G}$ proteins at the $\beta$ ARs, i.e., under physiological conditions it suppresses G-protein activation by the cardiac $\beta$ ARs [81]. In addition, the notion that carvedilol is a $\beta$-arrestin- "biased" ligand has been challenged by a variety of studies [136-138]. Therefore, they await confirmation in physiologically relevant in vitro settings, and, of course, in vivo. If proven true, then it is quite plausible that the $\beta_{1} \mathrm{AR}$ interacts with $\mathrm{Gi} \alpha$ to induce downstream cardioprotective signaling pathways that involve $\beta$-arrestins, PI3K and cGMP/PKG. However, the notion that cardiac $\beta_{1} \mathrm{AR}$ signaling can turn cardioprotective in the failing heart goes directly against the consensus that selective cardiac $\beta_{1}$ AR downregulation, a molecular hallmark of chronic human HF, serves as an adaptive homeostatic process employed by the failing myocardium to shield itself against the chronic catecholaminergic stress in HF, which results from the chronically elevated SNS activity that accompanies and aggravates human $\mathrm{HF}$ [2]. Adding more complexity to cardiac $\beta \mathrm{AR}$ signaling in $\mathrm{HF}, \beta_{2} \mathrm{AR}$ was recently reported to restrict $\beta_{1} A R$ signaling into specific subcellular compartments [139]. This was mediated by GRK2-dependent phosphorylation and subsequent $\beta$-arrestin1-mediated phosphodiesterase (PDE)-4 recruitment.

Cardiac fibroblasts represent $\sim 20-30 \%$ of the total cardiac cell number under physiological conditions (these percentages can vary significantly depending on the presence of diseases and on the state of this disease) [86]. In contrast to cardiac myocytes, cardiac fibroblasts mainly express the $\beta_{2} A R$ subtype [140]. Whether $\beta_{2} A R$ promotes or inhibits cardiac the proliferation and the activation of fibroblasts is still a matter of intense investigation [141]. On one hand, some studies have shown that $\beta_{2} A R$ may stimulate cell proliferation and pro-inflammatory/pro-fibrotic gene expression in cardiac fibroblasts [141-143]. In fact, GRK2 plays a key role in myocardial fibrogenesis [144] and $\beta_{2} A R$ has been shown to promote interleukin (IL)-6 secretion and hypertrophy [141,145]. Moreover, $\beta_{1} / \beta_{2}$ AR double knockout mice exhibited significantly less interstitial fibrosis and fibrotic mediator expression (TGF $\beta$, CTGF, collagen-III) in response to TAC, compared to control animals [146]. Furthermore, fibroblast-restricted genetic deletion of $\beta_{2}$ AR led to prevention of isoproterenol-induced cardiac hypertrophy, dysfunction and fibrosis in transgenic mice [91]. On the other hand, cAMP and especially its effector Epac1, has been associated with anti-fibrotic signaling in various tissues, including in the heart, and $\beta_{2} \mathrm{AR}$ 
was recently shown to inhibit cardiac fibrosis via cAMP in vitro, in a mechanism involving cAMP and Epac1, an effect opposed by the pro-inflammatory cytokine osteopontin and GRK2 [86,147,148].

In addition to $\beta$ ARs, $\alpha_{1}$ ARs are also present in mammalian cardiomyocytes, with the $\alpha_{1 \mathrm{~A}} \alpha_{1 \mathrm{~B}}$ subtypes accounting for $\sim 10 \%$ of total AR number in the healthy adult myocardium [149]. $\alpha_{1 \mathrm{~B}} \mathrm{AR}$ appears to have detrimental consequences for the failing myocardium $[149,150]$, whereas the $\alpha_{1 \mathrm{~A}}$ AR subtype seems to be beneficial in HF. Interestingly, deletion of both subtypes leads to enhanced TAC-induced apoptosis, cardiac dilatation, and reduced survival in mice [151]. On the one hand, cardiac-specific $\alpha_{1 B} A R$ overexpression results in severe pressure overload-induced hypertrophy, fibrosis, and HF [152]. On the other hand, $\alpha_{1 \mathrm{~A}} \mathrm{AR}$ knockout increases cardiac apoptosis/necrosis in response to NE, doxorubicin, or oxidative stress [153]. In addition, $\alpha_{1 \mathrm{~A}} \mathrm{AR}$ activation protects the heart against pressure overload through its classic $\mathrm{G}_{\mathrm{q} / 11}$ protein signaling [154].

From a mechanistic point of view, $\alpha_{1 \mathrm{~A}} \mathrm{AR}$-dependent cardioprotection is mediated by protein kinase $C$ (PKC), a protein that promotes glucose transporter (GLUT)-1/4 activity to enhance glucose metabolism, by ERK activation to prevent apoptosis, and via pro-angiogenic signaling [154,155]. Furthermore, cardiac $\alpha_{1 \mathrm{~A}} \mathrm{AR}$ overexpression leads to augmented contractility without accompanying hypertrophy or fibrosis [156], and $\alpha_{1 \mathrm{~A}} \mathrm{AR}$ activation is essential for preservation of cardiac function and survival post-TAC or upon doxorubicin challenge $[157,158]$. Both $\alpha_{1 \mathrm{~A}} \mathrm{AR}$ and $\alpha_{1 \mathrm{~B}} \mathrm{AR}$ subtypes have been shown to be expressed in failing human heart, and, interestingly enough, to resist downregulation in the failing human heart [159]. This is consistent with data showing that $\alpha_{1 \mathrm{~A}}$ AR-dependent positive inotropy being intact in hearts from HF patients [160]. The extent of positive inotropy exerted by $\alpha_{1 \mathrm{~A}}$ AR remains somewhat controversial but, at the molecular level, it is presumably mediated by increased intracellular $\mathrm{Ca}^{2+}$ signaling and RhoA-dependent kinase (ROCK) activation [161,162]. Transient receptor potential channel (TRPC)-6 activation and subcellular translocation may also be involved [162].

Finally, with regard to cardiac $\alpha_{2}$ ARs, NE release of NE from cardiac SNS terminals is controlled by both presynaptic $\alpha_{2 A^{-}}$and $\alpha_{2 C}$ ARs [163]. In fact, genetic knockout of both results in cardiac hypertrophy and $\mathrm{HF}$, due to chronically elevated NE levels. Epi levels are increased also, as a result of augmented adrenal secretion $[164,165]$. Interestingly, $\alpha_{2}$ ARs act as presynaptic inhibitory auto-receptors not only in cardiac SNS terminals but also in the chromaffin cells of the adrenal medulla, wherein they prevent further Epi and NE release [166]. This process is under tonic control of adrenal GRK2 (acting in concert with $\beta$-arrestin1), given that adrenal GRK2 upregulation is a molecular hallmark of the SNS hyperactivity that accompanies chronic HF $[115,167,168]$. Indeed, GRK2 upregulation in pre-ganglionic sympathetic nerves innervating the adrenal medulla promotes TAC-induced SNS hyperactivity [169]. Supporting this data, some authors have published that a human polymorphic $\alpha_{2 B} A R$ variant resistant to GRK2-dependent phosphorylation and desensitization provides augmented sympatholysis in a transfected chromaffin cell line [170]. Another human $\alpha_{2} \mathrm{AR}$ polymorphic variant, the Ins/Del322-325 $\alpha_{2 \mathrm{C}} \mathrm{AR}$, which is quite frequent in African-American HF patients and which shows diminished sympatholytic capacity to inhibit NE release from cardiac SNS terminals, significantly affects HF risk and prognosis in patients, when this is examined in conjunction with the hyperfunctional Agr389 variant of the human $\beta_{1} A R$ [171]. Indeed, the combined presence of Arg389 $\beta_{1} A R$ together with Del322-325 $\alpha_{2 \mathrm{C}} \mathrm{AR}$ can prognosticate the clinical response to the $\beta$-blocker bucindolol in black HF patients [172].

\section{Aldosterone-Induced Adrenergic Receptor Dysfunction in the Failing Myocardium}

Aldosterone is produced from the adrenal cortex in response to hyperkalemia or angiotensin II stimulation of its type 1 receptor $\left(\mathrm{AT}_{1} \mathrm{R}\right)$. Its production is elevated in chronic human HF [173]. Adrenal $\beta$-arrestin1-dependent $\mathrm{AT}_{1} \mathrm{R}$ signaling promotes aldosterone synthesis and secretion both in vitro and in vivo [174]. Moreover, inhibition of this pathway in the adrenal cortex in vivo markedly attenuates post-MI HF [175,176]. In fact, adrenal 
$\beta$-arrestin1 is absolutely essential for disease-associated hyperaldosteronism, since its absence results in normal circulating aldosterone levels even in the presence of MI [102]. Importantly, catecholamine-activated $\beta$ ARs were recently shown to enhance $A_{1} R$-dependent aldosterone production via GRK2-mediated receptor crosstalk in adrenocortical cells [177]. Thus, it appears that the catecholamine and aldosterone secretion pathways are intricately interposed in the adrenal gland via $\beta$-arrestin-dependent signaling $[178,179]$.

The direct effects of aldosterone or of its receptor (MR) on cardiac AR signaling and function have not been well studied. Studies from our laboratory have revealed that aldosterone can impair the cardiac $\beta_{2} \mathrm{AR}$ anti-fibrotic signaling mediated by cAMP via osteopontin transcriptional upregulation [148]. Osteopontin, a drug previously mentioned, is a pro-inflammatory / pro-fibrotic cytokine that has been shown to derange $\beta_{2} \mathrm{AR}$ signaling in various tissues, such as bone cells. We recently showed that, in H9c2 cardiomyocytes, its CRISPR/Cas9-mediated genetic deletion leads to augmented cAMP signaling by $\beta_{2} A R$, which protects against TGF $\beta$-induced fibrosis via Epac1 activation [148]. In addition, osteopontin seems to facilitate GRK2-mediated desensitization of this receptor, i.e., $\beta_{2} \mathrm{AR}-$ $G_{s}$ protein uncoupling, which further diminishes the anti-fibrotic actions of $\beta_{2} A R$ in cardiomyocytes and cardiac fibroblasts [86].

Interestingly, there appears to be a regulatory feedback loop between $\beta_{2} A R$ and aldosterone in the myocardium. Not only does aldosterone inhibit $\beta_{2} A R$ signaling via upregulation of osteopontin, but the $\beta_{2} \mathrm{AR}$ opposes aldosterone signaling in the heart via the cardiac MR by activating GRK5 [180] (Figure 1). Indeed, GRK2 phosphorylates and desensitizes the cardioprotective $G$ protein-coupled estrogen receptor (GPER) but GRK5 phosphorylates the MR in the cytoplasm to induce MR cytosolic retention and blockade of its transcriptional activity (Figure 1). Of note, this so-called "non-canonical" effect of GRK5, given that the MR is not a GPCR, is antithetical to the kinase's nuclear/genomic effects as a class II histone deacetylase (HDAC) kinase, which are largely harmful, as they promote pathological hypertrophy [181]. Indeed, subcellular localization of GRK5 seems to dictate the nature of the cardiac actions of this kinase: inside the nucleus it promotes maladaptive hypertrophy but, in the cytoplasm, it may afford cardio-protection against aldosterone [180-183]. It is important to note that the overall balance of GRK5's effects on the myocardium, i.e., whether it is positive or negative, remains controversial with some studies reporting a beneficial, protective role for GRK5 in the myocardium, including attenuation of atherosclerosis and cardiac nuclear factor (NF)-КB NF inhibition [184-187], but some others reporting adverse remodeling effects like promotion of fibrosis [188,189]. Finally, regarding the precise signaling mechanism underlying the inhibitory phosphorylation of the MR by GRK5 in the cytoplasm, we know that $\beta_{2} A R$ needs to activate a non-conventional PLC $\beta-\mathrm{Ca}^{2+}-\mathrm{CaMKII}$ pathway, normally activated by $\mathrm{G}_{\mathrm{q}}$ protein-coupled receptors, which then triggers the "shedding" of GRK5 from the cell membrane, where it normally resides bound to membrane phospholipids via a polybasic amino acid region of its C-terminus, into the cytoplasm [180,190] (Figure 1). Interestingly, the $\beta_{1} \mathrm{AR}$ seems incapable of activating this signaling pathway and, in fact, it may even inhibit it $[180,191]$.

Beyond GRK5 and osteopontin, there are some other molecular/signaling "points" of crosstalk between aldosterone and ARs that may operate in myocardial cells. One of them is ERK phosphorylation and activation. Indeed, aldosterone antagonism with eplerenone has been shown to inhibit $\beta A R$-dependent cardiac fibrosis in primary cardiac fibroblasts, as well as in rat left ventricles via blockade of isoproterenol-induced ERK phosphorylation (Figure 1), of 11 $\beta$-hydroxysteroid dehydrogenase type I (11 $\beta$-HSD1), and of collagen expressions [192]. This suggests that aldosterone can mediate catecholamineelicited pro-fibrotic signaling in the heart. cAMP-responsive element binding protein (CREB) phosphorylation and activation might be another point where aldosterone and $\beta A R$ signaling intercalate at (Figure 1) [193]. CREB is a pivotal transcription factor that crucially mediates $\beta A R$-induced gene transcription/expression and MR seems capable of inhibiting CREB activity via calcineurin/protein phosphatase (PP)-2B activation [193]. Nevertheless, whether this occurs in cardiac cells or in the myocardium in vivo remains to be seen. Of 
note, GRK2 was recently shown to mediate sustained activation of $\alpha 2$ AR-stimulated CREB in neuronal cells [194]. Furthermore, $\alpha_{1}$ AR signaling may also crosstalk with aldosterone and the MR at the level of PKC activation (Figure 1). In fact, it has been reported that both $\alpha_{1} \mathrm{AR}$ activation by phenylephrine and PKC activation with phorbol esters upregulates corticosteroid pro-hypertrophic signaling in cardiomyocytes, while, in turn, aldosterone (and corticosterone) promotes phenylephrine-elicited hypertrophy and other remodeling effects in neonatal rat ventricular myocytes, in part thanks to hypertrophy-induced cardiac MR upregulation and serum/glucocorticoid-induced kinase (SGK)-1 activation [195].

\section{Cardiac myocyte or fibroblast}

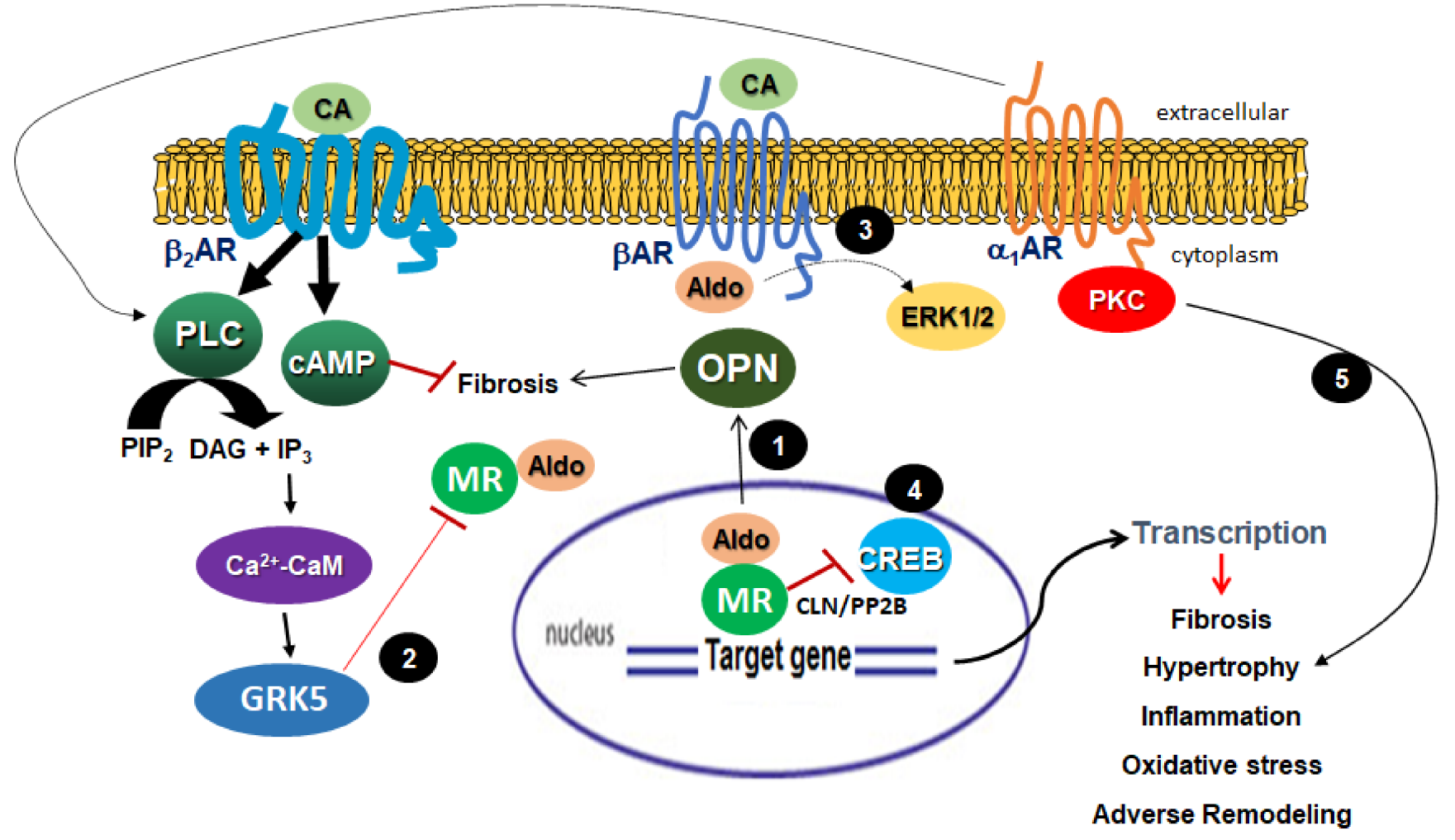

Figure 1. Five emerging molecular points of aldosterone-AR signaling crosstalk in the heart. 1. OPN is transcriptionally upregulated by aldosterone and, in turn, dampens the cAMP-mediated anti-fibrotic signaling of the $\beta_{2} \mathrm{AR} ; 2$. $\beta_{2} \mathrm{AR}-$ stimulated GRK5 "sheds" from the plasma membrane to the cytoplasm, wherein it phosphorylates and inhibits MR (prevents MR nuclear translocation); 3. Aldosterone enhances catecholamine ( $\beta \mathrm{AR}$ )-mediated ERK activation resulting in enhanced fibrosis; 4. MR inhibits CREB (usually activated by $\beta$ ARs) via CLN/PP2B; $5 . \alpha_{1}$ AR-activated PKC enhances aldosterone-induced hypertrophy and adverse remodeling. Adapted from Parker at al., 2018 [3].

\section{Conclusions and Future Perspectives}

More studies are warranted to further elucidate the molecules representing signaling connections between aldosterone-MR and AR signaling in the heart in different subcellular locations, including mitochondria. Given that the MR is not the only receptor activated by aldosterone, the picture can get quite complicated. Only a combination of in vitro and in vivo studies in both animal models and humans can help bring it into a better focus. Moreover, by studying the clinical effects of mineralocorticoid antagonists in HF patients, indirect insights into the role aldosterone plays in adrenergic regulation of cardiac function and morphology can be gleaned.

What is known with certainty is that the cardiac MR displays significant bidirectional signaling crosstalk with various GPCRs, including the ARs. In other words, aldosterone modulates AR function, number, and signaling, but also ARs modulate the actions of aldosterone (through MR) in the heart. Moreover, the effects of aldosterone in mitochondrial 
dysfunction have been proposed, even if the molecular mechanisms underlying these effects are not yet totally understood. The advent of novel, non-steroidal aldosterone antagonists (e.g., finerenone), which are purportedly more potent and specific inhibitors of the MR, represent another opportunity to gather novel insights into the interplay between $\mathrm{AR}$ and aldosterone signaling in the failing myocardium. Furthermore, the use of mitochondria as a pharmacological target will pave the road to new pharmacological therapies in this condition. Moreover, delineation of all signaling crosstalk mechanisms connecting aldosterone/MR and ARs in the heart has the enormous potential for delivering novel, safer, and more effective therapies for human chronic HF towards achieving the "holy grail" of precision medicine also for heart disease. Aided by methodological and technological advances in the field of GPCR structural biology, physiology, and pharmacology, future studies on the aldosterone-AR signaling reciprocity in different subcellular compartments, including mitochondria, might one day lead to the addition of better, more targeted, and personalized weapons into the future cardiologist's therapeutic arsenal.

Author Contributions: Writing—original draft preparation: M.G.-M., P.U. and J.I.B. Writing—review and editing: A.L. and M.E.S. All authors have read and agreed to the published version of the manuscript.

Funding: Preparation of this manuscript was supported by the National Institutes of Health (4R00AG055701-03 to MES, GM115570-01A1 to EVP), and by Rutgers University (Start Up funds to MES).

Institutional Review Board Statement: Not applicable.

Informed Consent Statement: Not applicable.

Data Availability Statement: Not applicable.

Conflicts of Interest: The authors declare no conflict of interest.

Abbreviations
$\begin{array}{ll}\text { Please see text for details and for all other molecular acronym descriptions: } \\ \text { Aldo } & \text { Aldosterone } \\ \mathrm{Ca}^{2+} \text {-CaM } & \text { Calcium-bound calmodulin } \\ \text { CA } & \text { Catecholamine } \\ \text { cAMP } & \text { Cyclic } 3^{\prime}, 5^{\prime} \text {-adenosine monophosphate } \\ \text { CLN } & \text { Calcineurin } \\ \text { CREB } & \text { cAMP response element-binding protein } \\ \text { DAG } & 2^{\prime} \text {-Diacylglycerol } \\ \text { ERK } & \text { Extracellular signal-regulate kinase } \\ \text { GRK5 } & \text { G protein-coupled receptor kinase-5 } \\ \text { IP } 3 & \text { Inositol } 1^{\prime}, 4^{\prime}, 5^{\prime} \text {-trisphopshate } \\ \text { OPN } & \text { Osteopontin } \\ \text { PIP2 } & \text { Phosphatidylinositol } 4^{\prime}, 5^{\prime} \text {-bisphosphate } \\ \text { PKC } & \text { Protein kinase C } \\ \text { PLC } & \text { Phospholipase C } \\ \text { PP2B } & \text { Protein phosphatase-2B }\end{array}$

\section{References}

1. Savarese, G.; Lund, L.H. Global Public Health Burden of Heart Failure. Card. Fail. Rev. 2017, 3, 7-11. [CrossRef]

2. Lymperopoulos, A.; Rengo, G.; Koch, W.J. Adrenergic nervous system in heart failure: Pathophysiology and therapy. Circ. Res. 2013, 113, 739-753. [CrossRef]

3. Parker, B.M.; Wertz, S.L.; Pollard, C.M.; Desimine, V.L.; Maning, J.; McCrink, K.A.; Lymperopoulos, A. Novel Insights into the Crosstalk between Mineralocorticoid Receptor and G Protein-Coupled Receptors in Heart Adverse Remodeling and Disease. Int. J. Mol. Sci. 2018, 19, 3764. [CrossRef] [PubMed]

4. Parati, G.; Esler, M. The human sympathetic nervous system: Its relevance in hypertension and heart failure. Eur. Heart J. 2012, 33, 1058-1066. [CrossRef] [PubMed] 
5. Grassi, G.; Quarti-Trevano, F.; Esler, M.D. Sympathetic activation in congestive heart failure: An updated overview. Heart Fail. Rev. 2021, 26, 173-182. [CrossRef]

6. Cohn, J.N. Abnormalities of peripheral sympathetic nervous system control in congestive heart failure. Circulation 1990, 82, I59-I67.

7. Solesio, M.E.; Saez-Atienzar, S.; Jordan, J.; Galindo, M.F. 3-Nitropropionic acid induces autophagy by forming mitochondrial permeability transition pores rather than activating the mitochondrial fission pathway. Br. J. Pharm. 2013, 168, 63-75. [CrossRef]

8. Solesio, M.E.; Saez-Atienzar, S.; Jordan, J.; Galindo, M.F. Characterization of mitophagy in the 6-hydoxydopamine Parkinson's disease model. Toxicol. Sci. 2012, 129, 411-420. [CrossRef]

9. Solesio, M.E.; Prime, T.A.; Logan, A.; Murphy, M.P.; Del Mar Arroyo-Jimenez, M.; Jordan, J.; Galindo, M.F. The mitochondriatargeted anti-oxidant MitoQ reduces aspects of mitochondrial fission in the 6-OHDA cell model of Parkinson's disease. Biochim. Biophys. Acta 2013, 1832, 174-182. [CrossRef]

10. Solesio, M.E.; Peixoto, P.M.; Debure, L.; Madamba, S.M.; de Leon, M.J.; Wisniewski, T.; Pavlov, E.V.; Fossati, S. Carbonic anhydrase inhibition selectively prevents amyloid $\beta$ neurovascular mitochondrial toxicity. Aging Cell 2018, 17, e12787. [CrossRef]

11. Liu, Z.; Solesio, M.E.; Schaffler, M.B.; Frikha-Benayed, D.; Rosen, C.J.; Werner, H.; Kopchick, J.J.; Pavlov, E.V.; Abramov, A.Y.; Yakar, S. Mitochondrial Function Is Compromised in Cortical Bone Osteocytes of Long-Lived Growth Hormone Receptor Null Mice. J. Bone Miner. Res. 2019, 34, 106-122. [CrossRef] [PubMed]

12. Galindo, M.F.; Solesio, M.E.; Atienzar-Aroca, S.; Zamora, M.J.; Jordan Bueso, J. Mitochondrial dynamics and mitophagy in the 6-hydroxydopamine preclinical model of Parkinson's disease. Parkinsons Dis. 2012, 2012, 131058. [CrossRef]

13. Borden, E.A.; Furey, M.; Gattone, N.J.; Hambardikar, V.D.; Liang, X.H.; Scoma, E.R.; Abou Samra, A.; LR, D.G.; Dennis, D.J.; Fricker, D.; et al. Is there a link between inorganic polyphosphate (polyP), mitochondria, and neurodegeneration? Pharm. Res. 2020, 105211. [CrossRef]

14. Baltanas, A.; Solesio, M.E.; Zalba, G.; Galindo, M.F.; Fortuno, A.; Jordan, J. The senescence-accelerated mouse prone-8 (SAM-P8) oxidative stress is associated with upregulation of renal NADPH oxidase system. J. Physiol. Biochem. 2013, 69, 927-935. [CrossRef]

15. Solesio, M.E.; Mitaishvili, E.; Lymperopoulos, A. Adrenal ßarrestin1 targeting for tobacco-associated cardiac dysfunction treatment: Aldosterone production as the mechanistic link. Pharm. Res. Perspect. 2019, 7, e00497. [CrossRef]

16. Miyata, K.; Rahman, M.; Shokoji, T.; Nagai, Y.; Zhang, G.X.; Sun, G.P.; Kimura, S.; Yukimura, T.; Kiyomoto, H.; Kohno, M.; et al. Aldosterone stimulates reactive oxygen species production through activation of NADPH oxidase in rat mesangial cells. J. Am. Soc. Nephrol. 2005, 16, 2906-2912. [CrossRef] [PubMed]

17. Hayashi, H.; Kobara, M.; Abe, M.; Tanaka, N.; Gouda, E.; Toba, H.; Yamada, H.; Tatsumi, T.; Nakata, T.; Matsubara, H. Aldosterone nongenomically produces NADPH oxidase-dependent reactive oxygen species and induces myocyte apoptosis. Hypertens Res. 2008, 31, 363-375. [CrossRef] [PubMed]

18. Knowlton, A.A.; Chen, L.; Malik, Z.A. Heart failure and mitochondrial dysfunction: The role of mitochondrial fission/fusion abnormalities and new therapeutic strategies. J. Cardiovasc. Pharm. 2014, 63, 196-206. [CrossRef]

19. Villar, P.; Breton, B.; Garcia-Pavia, P.; Gonzalez-Paramos, C.; Blazquez, A.; Gomez-Bueno, M.; Garcia-Silva, T.; Garcia-Consuegra, I.; Martin, M.A.; Garesse, R.; et al. Cardiac dysfunction in mitochondrial disease. Clinical and molecular features. Circ. J. 2013, 77, 2799-2806. [CrossRef] [PubMed]

20. Lesnefsky, E.J.; Moghaddas, S.; Tandler, B.; Kerner, J.; Hoppel, C.L. Mitochondrial dysfunction in cardiac disease: Ischemiareperfusion, aging, and heart failure. J. Mol. Cell Cardiol. 2001, 33, 1065-1089. [CrossRef]

21. Ibarrola, J.; Sadaba, R.; Martinez-Martinez, E.; Garcia-Pena, A.; Arrieta, V.; Alvarez, V.; Fernandez-Celis, A.; Gainza, A.; Cachofeiro, V.; Santamaria, E.; et al. Aldosterone Impairs Mitochondrial Function in Human Cardiac Fibroblasts via A-Kinase Anchor Protein 12. Sci. Rep. 2018, 8, 6801. [CrossRef]

22. Chistiakov, D.A.; Shkurat, T.P.; Melnichenko, A.A.; Grechko, A.V.; Orekhov, A.N. The role of mitochondrial dysfunction in cardiovascular disease: A brief review. Ann. Med. 2018, 50, 121-127. [CrossRef] [PubMed]

23. Rosca, M.G.; Hoppel, C.L. Mitochondrial dysfunction in heart failure. Heart Fail. Rev. 2013, 18, 607-622. [CrossRef]

24. Tong, M.; Zablocki, D.; Sadoshima, J. The role of Drp1 in mitophagy and cell death in the heart. J. Mol. Cell Cardiol. 2020, 142, 138-145. [CrossRef]

25. Tsutsui, H.; Kinugawa, S.; Matsushima, S. Oxidative stress and heart failure. Am. J. Physiol. Heart Circ. Physiol. 2011, 301, H2181-H2190. [CrossRef]

26. Yao, K.; Zhang, W.W.; Yao, L.; Yang, S.; Nie, W.; Huang, F. Carvedilol promotes mitochondrial biogenesis by regulating the PGC-1/TFAM pathway in human umbilical vein endothelial cells (HUVECs). Biochem. Biophys. Res. Commun. 2016, 470, 961-966. [CrossRef]

27. Saraste, M. Oxidative phosphorylation at the fin de siecle. Science 1999, 283, 1488-1493. [CrossRef]

28. Schieber, M.; Chandel, N.S. ROS function in redox signaling and oxidative stress. Curr. Biol. 2014, 24, R453-R462. [CrossRef] [PubMed]

29. Solesio, M.E.; Elustondo, P.A.; Zakharian, E.; Pavlov, E.V. Inorganic polyphosphate (polyP) as an activator and structural component of the mitochondrial permeability transition pore. Biochem. Soc. Trans. 2016, 44, 7-12. [CrossRef] [PubMed]

30. Solesio, M.E.; Garcia Del Molino, L.C.; Elustondo, P.A.; Diao, C.; Chang, J.C.; Pavlov, E.V. Inorganic polyphosphate is required for sustained free mitochondrial calcium elevation, following calcium uptake. Cell Calcium 2020, 86, 102127. [CrossRef] 
31. Solesio, M.E.; Xie, L.; McIntyre, B.; Ellenberger, M.; Mitaishvili, E.; Bhadra-Lobo, S.; Bettcher, L.F.; Bazil, J.N.; Raftery, D.; Jakob, U.; et al. Depletion of mitochondrial inorganic polyphosphate (polyP) in mammalian cells causes metabolic shift from oxidative phosphorylation to glycolysis. Biochem. J. 2021, 478, 1631-1646. [CrossRef]

32. Seidlmayer, L.K.; Gomez-Garcia, M.R.; Shiba, T.; Porter, G.A., Jr.; Pavlov, E.V.; Bers, D.M.; Dedkova, E.N. Dual role of inorganic polyphosphate in cardiac myocytes: The importance of polyP chain length for energy metabolism and mPTP activation. Arch. Biochem. Biophys. 2019, 662, 177-189. [CrossRef]

33. Seidlmayer, L.K.; Gomez-Garcia, M.R.; Blatter, L.A.; Pavlov, E.; Dedkova, E.N. Inorganic polyphosphate is a potent activator of the mitochondrial permeability transition pore in cardiac myocytes. J. Gen. Physiol. 2012, 139, 321-331. [CrossRef]

34. Seidlmayer, L.K.; Blatter, L.A.; Pavlov, E.; Dedkova, E.N. Inorganic polyphosphate-an unusual suspect of the mitochondrial permeability transition mystery. Channels 2012, 6, 463-467. [CrossRef]

35. Chen, D.; Li, X.; Zhang, L.; Zhu, M.; Gao, L. A high-fat diet impairs mitochondrial biogenesis, mitochondrial dynamics, and the respiratory chain complex in rat myocardial tissues. J. Cell. Biochem. 2018, 119, 9602. [CrossRef]

36. Birner, C.; Dietl, A.; Deutzmann, R.; Schröder, J.; Schmid, P.; Jungbauer, C.; Resch, M.; Endemann, D.; Stark, K.; Riegger, G. Proteomic profiling implies mitochondrial dysfunction in tachycardia-induced heart failure. J. Card. Fail. 2012, 18, 660-673. [CrossRef] [PubMed]

37. Dabkowski, E.R.; Baseler, W.A.; Williamson, C.L.; Powell, M.; Razunguzwa, T.T.; Frisbee, J.C.; Hollander, J.M. Mitochondrial dysfunction in the type 2 diabetic heart is associated with alterations in spatially distinct mitochondrial proteomes. Am. J. Physiol. Heart Circ. Physiol. 2010, 299, H529-H540. [CrossRef]

38. Melenovsky, V.; Petrak, J.; Mracek, T.; Benes, J.; Borlaug, B.A.; Nuskova, H.; Pluhacek, T.; Spatenka, J.; Kovalcikova, J.; Drahota, Z.; et al. Myocardial iron content and mitochondrial function in human heart failure: A direct tissue analysis. Eur. J. Heart Fail. 2017, 19, 522-530. [CrossRef] [PubMed]

39. Hahn, V.S.; Knutsdottir, H.; Luo, X.; Bedi, K.; Margulies, K.B.; Haldar, S.M.; Stolina, M.; Yin, J.; Khakoo, A.Y.; Vaishnav, J.; et al. Myocardial Gene Expression Signatures in Human Heart Failure With Preserved Ejection Fraction. Circulation 2021, 143, 120-134. [CrossRef] [PubMed]

40. Sheeran, F.L.; Pepe, S. Mitochondrial bioenergetics and dysfunction in failing heart. Mitochondrial Dyn. Cardiovasc. Med. 2017, 65-80.

41. Kiyuna, L.A.; e Albuquerque, R.P.; Chen, C.-H.; Mochly-Rosen, D.; Ferreira, J.C.B. Targeting mitochondrial dysfunction and oxidative stress in heart failure: Challenges and opportunities. Free Radic. Biol. Med. 2018, 129, 155-168. [CrossRef]

42. Ribeiro Junior, R.F.; Dabkowski, E.R.; Shekar, K.C.; KA, O.C.; Hecker, P.A.; Murphy, M.P. MitoQ improves mitochondrial dysfunction in heart failure induced by pressure overload. Free Radic. Biol. Med. 2018, 117, 18-29. [CrossRef] [PubMed]

43. Bollag, W.B. Regulation of aldosterone synthesis and secretion. Compr. Physiol. 2014, 4, 1017-1055. [PubMed]

44. Gomez-Sanchez, E.; Gomez-Sanchez, C.E. The multifaceted mineralocorticoid receptor. Compr. Physiol. 2014, 4, 965-994.

45. Alhayek, S.; Preuss, C.V. Beta 1 Receptors. In StatPearls; StatPearls Publishing: Treasure Island, FL, USA, 2021. Available online: https:/ / pubmed.ncbi.nlm.nih.gov/30422499/ (accessed on 3 May 2021).

46. De Giusti, V.C.; Caldiz, C.I.; Ennis, I.L.; Perez, N.G.; Cingolani, H.E.; Aiello, E.A. Mitochondrial reactive oxygen species (ROS) as signaling molecules of intracellular pathways triggered by the cardiac renin-angiotensin II-aldosterone system (RAAS). Front. Physiol. 2013, 4, 126. [CrossRef] [PubMed]

47. Daubert, M.A.; Yow, E.; Dunn, G.; Marchev, S.; Barnhart, H.; Douglas, P.S.; O'Connor, C.; Goldstein, S.; Udelson, J.E.; Sabbah, H.N. Novel Mitochondria-Targeting Peptide in Heart Failure Treatment: A Randomized, Placebo-Controlled Trial of Elamipretide. Circ. Heart Fail. 2017, 10. [CrossRef]

48. Ferreira, J.C.; Koyanagi, T.; Palaniyandi, S.S.; Fajardo, G.; Churchill, E.N.; Budas, G.; Disatnik, M.H.; Bernstein, D.; Brum, P.C.; Mochly-Rosen, D. Pharmacological inhibition of $\beta$ IIPKC is cardioprotective in late-stage hypertrophy. J. Mol. Cell Cardiol. 2011, 51, 980-987. [CrossRef]

49. Ferreira, J.C.; Boer, B.N.; Grinberg, M.; Brum, P.C.; Mochly-Rosen, D. Protein quality control disruption by PKC $\beta I I$ in heart failure; rescue by the selective PKC $\beta$ II inhibitor, $\beta$ IIV5-3. PLoS ONE 2012, 7, e33175. [CrossRef]

50. Budas, G.; Costa, H.M., Jr.; Ferreira, J.C.; Teixeira da Silva Ferreira, A.; Perales, J.; Krieger, J.E.; Mochly-Rosen, D.; Schechtman, D. Identification of epsilonPKC targets during cardiac ischemic injury. Circ. J. 2012, 76, 1476-1485. [CrossRef]

51. Churchill, E.N.; Ferreira, J.C.; Brum, P.C.; Szweda, L.I.; Mochly-Rosen, D. Ischaemic preconditioning improves proteasomal activity and increases the degradation of deltaPKC during reperfusion. Cardiovasc. Res. 2010, 85, 385-394. [CrossRef]

52. Picca, A.; Mankowski, R.T.; Burman, J.L.; Donisi, L.; Kim, J.S.; Marzetti, E.; Leeuwenburgh, C. Mitochondrial quality control mechanisms as molecular targets in cardiac ageing. Nat. Rev. Cardiol. 2018, 15, 543-554. [CrossRef]

53. Westermann, B. Mitochondrial fusion and fission in cell life and death. Nat. Rev. Mol. Cell Biol. 2010, 11, 872-884. [CrossRef]

54. Green, D.R.; Van Houten, B. SnapShot: Mitochondrial quality control. Cell 2011, 147, 950.e1. [CrossRef] [PubMed]

55. Youle, R.J.; Narendra, D.P. Mechanisms of mitophagy. Nat. Rev. Mol. Cell Biol. 2011, 12, 9-14. [CrossRef]

56. Shirakabe, A.; Zhai, P.; Ikeda, Y.; Saito, T.; Maejima, Y.; Hsu, C.P.; Nomura, M.; Egashira, K.; Levine, B.; Sadoshima, J. Drp1Dependent Mitochondrial Autophagy Plays a Protective Role Against Pressure Overload-Induced Mitochondrial Dysfunction and Heart Failure. Circulation 2016, 133, 1249-1263. [CrossRef] [PubMed]

57. Wai, T.; Garcia-Prieto, J.; Baker, M.J.; Merkwirth, C.; Benit, P.; Rustin, P.; Ruperez, F.J.; Barbas, C.; Ibanez, B.; Langer, T. Imbalanced OPA1 processing and mitochondrial fragmentation cause heart failure in mice. Science 2015, 350, aad0116. [CrossRef] 
58. Fountain, J.H.; Lappin, S.L. Physiology, Renin Angiotensin System. In StatPearls; StatPearls Publishing: Treasure Island, FL, USA, 2021. Available online: https:/ / pubmed.ncbi.nlm.nih.gov/29261862/ (accessed on 3 May 2021).

59. Grossmann, C.; Krug, A.W.; Freudinger, R.; Mildenberger, S.; Voelker, K.; Gekle, M. Aldosterone-induced EGFR expression: Interaction between the human mineralocorticoid receptor and the human EGFR promoter. Am. J. Physiol. Endocrinol. Metab. 2007, 292, E1790-E1800. [CrossRef]

60. Forrester, S.J.; Kawai, T.; O’Brien, S.; Thomas, W.; Harris, R.C.; Eguchi, S. Epidermal Growth Factor Receptor Transactivation: Mechanisms, Pathophysiology, and Potential Therapies in the Cardiovascular System. Annu. Rev. Pharm. Toxicol. 2016, 56, 627-653. [CrossRef]

61. Aroor, A.R.; Demarco, V.G.; Jia, G.; Sun, Z.; Nistala, R.; Meininger, G.A.; Sowers, J.R. The role of tissue Renin-Angiotensinaldosterone system in the development of endothelial dysfunction and arterial stiffness. Front. Endocrinol. 2013, 4, 161. [CrossRef]

62. Brown, N.J. Contribution of aldosterone to cardiovascular and renal inflammation and fibrosis. Nat. Rev. Nephrol. 2013, 9, 459-469. [CrossRef] [PubMed]

63. Tang, Y.; Long, J.; Liu, J. Hyperglycemia-Associated Oxidative Stress Induces Autophagy: Involvement of the ROS-ERK/JNKp53 Pathway. In Autophagy: Cancer, Other Pathologies, Inflammation, Immunity, Infection, and Aging; Elsevier: Amsterdam, The Netherlands, 2014; pp. 105-115.

64. Lefranc, C.; Friederich-Persson, M.; Braud, L.; Palacios-Ramirez, R.; Karlsson, S.; Boujardine, N.; Motterlini, R.; Jaisser, F.; Nguyen Dinh Cat, A. MR (Mineralocorticoid Receptor) Induces Adipose Tissue Senescence and Mitochondrial Dysfunction Leading to Vascular Dysfunction in Obesity. Hypertension 2019, 73, 458-468. [CrossRef]

65. Diviani, D.; Osman, H.; Delaunay, M.; Kaiser, S. The role of A-kinase anchoring proteins in cardiac oxidative stress. Biochem. Soc. Trans. 2019, 47, 1341-1353. [CrossRef] [PubMed]

66. Perrino, C.; Feliciello, A.; Schiattarella, G.G.; Esposito, G.; Guerriero, R.; Zaccaro, L.; Del Gatto, A.; Saviano, M.; Garbi, C.; Carangi, R.; et al. AKAP121 downregulation impairs protective cAMP signals, promotes mitochondrial dysfunction, and increases oxidative stress. Cardiovasc. Res. 2010, 88, 101-110. [CrossRef]

67. Schmitz, B.; Brand, S.M.; Brand, E. Aldosterone signaling and soluble adenylyl cyclase-a nexus for the kidney and vascular endothelium. Biochim. Biophys. Acta 2014, 1842, 2601-2609. [CrossRef] [PubMed]

68. Spat, A.; Szanda, G. Mitochondrial cAMP and $\mathrm{Ca}^{2+}$ metabolism in adrenocortical cells. Pflügers Arch. 2018, 470, 1141-1148. [CrossRef]

69. Kamp, T.J.; Hell, J.W. Regulation of cardiac L-type calcium channels by protein kinase A and protein kinase C. Circ. Res. 2000, 87, 1095-1102. [CrossRef]

70. Reiken, S.; Lacampagne, A.; Zhou, H.; Kherani, A.; Lehnart, S.E.; Ward, C.; Huang, F.; Gaburjakova, M.; Gaburjakova, J.; Rosemblit, N.; et al. PKA phosphorylation activates the calcium release channel (ryanodine receptor) in skeletal muscle: Defective regulation in heart failure. J. Cell Biol. 2003, 160, 919-928. [CrossRef] [PubMed]

71. Luongo, T.S.; Lambert, J.P.; Yuan, A.; Zhang, X.; Gross, P.; Song, J.; Shanmughapriya, S.; Gao, E.; Jain, M.; Houser, S.R.; et al. The Mitochondrial Calcium Uniporter Matches Energetic Supply with Cardiac Workload during Stress and Modulates Permeability Transition. Cell Rep. 2015, 12, 23-34. [CrossRef]

72. Bhayana, V.; Alto, L.E.; Dhalla, N.S. The effects of $\beta$-adrenergic receptor blockers on heart mitochondrial metabolism. Gen. Pharm. 1980, 11, 271-274. [CrossRef]

73. Panchal, A.R.; Stanley, W.C.; Kerner, J.; Sabbah, H.N. Beta-receptor blockade decreases carnitine palmitoyl transferase I activity in dogs with heart failure. J. Card. Fail. 1998, 4, 121-126. [CrossRef]

74. Gómez, A.; Sánchez-Roman, I.; Gomez, J.; Cruces, J.; Mate, I.; Lopez-Torres, M.; Naudi, A.; Portero-Otin, M.; Pamplona, R.; De la Fuente, M. Lifelong treatment with atenolol decreases membrane fatty acid unsaturation and oxidative stress in heart and skeletal muscle mitochondria and improves immunity and behavior, without changing mice longevity. Aging Cell 2014, 13, 551-560. [CrossRef]

75. Zugck, C.; Haunstetter, A.; Kruger, C.; Kell, R.; Schellberg, D.; Kubler, W.; Haass, M. Impact of beta-blocker treatment on the prognostic value of currently used risk predictors in congestive heart failure. J. Am. Coll. Cardiol. 2002, 39, 1615-1622. [CrossRef]

76. O'Neill, J.O.; Young, J.B.; Pothier, C.E.; Lauer, M.S. Peak oxygen consumption as a predictor of death in patients with heart failure receiving $\beta$-blockers. Circulation 2005, 111, 2313-2318. [CrossRef]

77. Armour, J.A.; Murphy, D.A.; Yuan, B.X.; Macdonald, S.; Hopkins, D.A. Gross and microscopic anatomy of the human intrinsic cardiac nervous system. Anat. Rec. 1997, 247, 289-298. [CrossRef]

78. Lymperopoulos, A.; Rengo, G.; Koch, W.J. Adrenal adrenoceptors in heart failure: Fine-tuning cardiac stimulation. Trends Mol. Med. 2007, 13, 503-511. [CrossRef] [PubMed]

79. Capote, L.A.; Mendez Perez, R.; Lymperopoulos, A. GPCR signaling and cardiac function. Eur J. Pharm. 2015, 763, 143-148. [CrossRef] [PubMed]

80. Lymperopoulos, A. Arrestins in the Cardiovascular System: An Update. Prog. Mol. Biol. Transl. Sci. 2018, 159, $27-57$.

81. Yoshikawa, T.; Port, J.D.; Asano, K.; Chidiak, P.; Bouvier, M.; Dutcher, D.; Roden, R.L.; Minobe, W.; Tremmel, K.D.; Bristow, M.R. Cardiac adrenergic receptor effects of carvedilol. Eur. Heart J. 1996, 17 (Suppl. B), 8-16. [CrossRef] [PubMed]

82. Bers, D.M.; Shannon, T.R. Calcium movements inside the sarcoplasmic reticulum of cardiac myocytes. J. Mol. Cell Cardiol. 2013, 58, 59-66. [CrossRef] 
83. Daaka, Y.; Luttrell, L.M.; Lefkowitz, R.J. Switching of the coupling of the beta2-adrenergic receptor to different G proteins by protein kinase A. Nature 1997, 390, 88-91. [CrossRef]

84. Communal, C.; Singh, K.; Sawyer, D.B.; Colucci, W.S. Opposing effects of $\beta_{1}$ - and $\beta_{2}$-adrenergic receptors on cardiac myocyte apoptosis: Role of a pertussis toxin-sensitive G protein. Circulation 1999, 100, 2210-2212. [CrossRef]

85. Chesley, A.; Lundberg, M.S.; Asai, T.; Xiao, R.P.; Ohtani, S.; Lakatta, E.G.; Crow, M.T. The $\beta_{2}$-adrenergic receptor delivers an antiapoptotic signal to cardiac myocytes through $\mathrm{G}_{\mathrm{i}}$-dependent coupling to phosphatidylinositol 3'-kinase. Circ. Res. 2000, 87, 1172-1179. [CrossRef] [PubMed]

86. Lymperopoulos, A.; Cora, N.; Maning, J.; Brill, A.R.; Sizova, A. Signaling and function of cardiac autonomic nervous system receptors: Insights from the GPCR signalling universe. FEBS J. 2021, 288, 2645-2659. [CrossRef]

87. Hartupee, J.; Mann, D.L. Neurohormonal activation in heart failure with reduced ejection fraction. Nat. Rev. Cardiol. 2017, 14, 30-38. [CrossRef] [PubMed]

88. Cohn, J.N.; Levine, T.B.; Olivari, M.T.; Garberg, V.; Lura, D.; Francis, G.S.; Simon, A.B.; Rector, T. Plasma norepinephrine as a guide to prognosis in patients with chronic congestive heart failure. N. Engl. J. Med. 1984, 311, 819-823. [CrossRef] [PubMed]

89. Kingwell, B.A.; Thompson, J.M.; Kaye, D.M.; McPherson, G.A.; Jennings, G.L.; Esler, M.D. Heart rate spectral analysis, cardiac norepinephrine spillover, and muscle sympathetic nerve activity during human sympathetic nervous activation and failure. Circulation 1994, 90, 234-240. [CrossRef] [PubMed]

90. Xiao, H.; Li, H.; Wang, J.J.; Zhang, J.S.; Shen, J.; An, X.B.; Zhang, C.C.; Wu, J.M.; Song, Y.; Wang, X.Y.; et al. IL-18 cleavage triggers cardiac inflammation and fibrosis upon $\beta$-adrenergic insult. Eur. Heart J. 2018, 39, 60-69. [CrossRef]

91. Zhao, W.B.; Lu, Q.; Nguyen, M.N.; Su, Y.; Ziemann, M.; Wang, L.N.; Kiriazis, H.; Puthalakath, H.; Sadoshima, J.; Hu, H.Y.; et al. Stimulation of $\beta$-adrenoceptors up-regulates cardiac expression of galectin-3 and BIM through the Hippo signalling pathway. Br. J. Pharm. 2019, 176, 2465-2481. [CrossRef]

92. Du, X.J.; Gao, X.M.; Wang, B.; Jennings, G.L.; Woodcock, E.A.; Dart, A.M. Age-dependent cardiomyopathy and heart failure phenotype in mice overexpressing $\beta_{2}$-adrenergic receptors in the heart. Cardiovasc. Res. 2000, 48, 448-454. [CrossRef]

93. Engelhardt, S.; Hein, L.; Wiesmann, F.; Lohse, M.J. Progressive hypertrophy and heart failure in $\beta_{1}$-adrenergic receptor transgenic mice. Proc. Natl. Acad. Sci. USA 1999, 96, 7059-7064. [CrossRef]

94. Liggett, S.B.; Tepe, N.M.; Lorenz, J.N.; Canning, A.M.; Jantz, T.D.; Mitarai, S.; Yatani, A.; Dorn, G.W., 2nd. Early and delayed consequences of $\beta_{2}$-adrenergic receptor overexpression in mouse hearts: Critical role for expression level. Circulation 2000, 101, 1707-1714. [CrossRef]

95. Cleland, J.G.F.; Bunting, K.V.; Flather, M.D.; Altman, D.G.; Holmes, J.; Coats, A.J.S.; Manzano, L.; McMurray, J.J.V.; Ruschitzka, F.; van Veldhuisen, D.J.; et al. Beta-blockers in Heart Failure Collaborative, G. Beta-blockers for heart failure with reduced, mid-range, and preserved ejection fraction: An individual patient-level analysis of double-blind randomized trials. Eur. Heart J. 2018, 39, 26-35. [CrossRef] [PubMed]

96. Lechat, P.; Packer, M.; Chalon, S.; Cucherat, M.; Arab, T.; Boissel, J.P. Clinical effects of $\beta$-adrenergic blockade in chronic heart failure: A meta-analysis of double-blind, placebo-controlled, randomized trials. Circulation 1998, 98, 1184-1191. [CrossRef]

97. Lefkowitz, R.J.; Shenoy, S.K. Transduction of receptor signals by $\beta$-arrestins. Science 2005, 308, 512-517. [CrossRef] [PubMed]

98. Peter, P.S.; Brady, J.E.; Yan, L.; Chen, W.; Engelhardt, S.; Wang, Y.; Sadoshima, J.; Vatner, S.F.; Vatner, D.E. Inhibition of p38 $\alpha$ MAPK rescues cardiomyopathy induced by overexpressed $\beta_{2}$-adrenergic receptor, but not $\beta_{1}$-adrenergic receptor. J. Clin. Investig. 2007, 117, 1335-1343. [CrossRef] [PubMed]

99. Grisanti, L.A.; Schumacher, S.M.; Tilley, D.G.; Koch, W.J. Designer Approaches for G Protein-Coupled Receptor Modulation for Cardiovascular Disease. JACC Basic Transl. Sci. 2018, 3, 550-562. [CrossRef]

100. Conner, D.A.; Mathier, M.A.; Mortensen, R.M.; Christe, M.; Vatner, S.F.; Seidman, C.E.; Seidman, J.G. $\beta$-Arrestin1 knockout mice appear normal but demonstrate altered cardiac responses to $\beta$-adrenergic stimulation. Circ. Res. 1997, 81, 1021-1026. [CrossRef]

101. Watari, K.; Nakaya, M.; Nishida, M.; Kim, K.M.; Kurose, H. $\beta$-arrestin2 in infiltrated macrophages inhibits excessive inflammation after myocardial infarction. PLoS ONE 2013, 8, e68351. [CrossRef]

102. Bathgate-Siryk, A.; Dabul, S.; Pandya, K.; Walklett, K.; Rengo, G.; Cannavo, A.; De Lucia, C.; Liccardo, D.; Gao, E.; Leosco, D.; et al. Negative impact of $\beta$-arrestin-1 on post-myocardial infarction heart failure via cardiac and adrenal-dependent neurohormonal mechanisms. Hypertension 2014, 63, 404-412. [CrossRef] [PubMed]

103. McCrink, K.A.; Maning, J.; Vu, A.; Jafferjee, M.; Marrero, C.; Brill, A.; Bathgate-Siryk, A.; Dabul, S.; Koch, W.J.; Lymperopoulos, A. $\beta$-Arrestin2 Improves Post-Myocardial Infarction Heart Failure via Sarco(endo)plasmic Reticulum Ca ${ }^{2+}$-ATPase-Dependent Positive Inotropy in Cardiomyocytes. Hypertension 2017, 70, 972-981. [CrossRef]

104. McCrink, K.A.; Maning, J.; Vu, A.; Jafferjee, M.; Marrero, C.; Brill, A.; Bathgate-Siryk, A.; Dabul, S.; Koch, W.J.; Lymperopoulos, A. Cardiac ßarrestin2 Improves Contractility and Adverse Remodeling in Heart Failure, But Is Underexpressed in Humans. J. Am. Coll. Cardiol. 2017, 70, 2948-2949. [CrossRef] [PubMed]

105. Bristow, M.R.; Hershberger, R.E.; Port, J.D.; Gilbert, E.M.; Sandoval, A.; Rasmussen, R.; Cates, A.E.; Feldman, A.M. Beta-adrenergic pathways in nonfailing and failing human ventricular myocardium. Circulation 1990, 82, I12-I25.

106. Bohm, M.; Flesch, M.; Schnabel, P. Role of G-proteins in altered $\beta$-adrenergic responsiveness in the failing and hypertrophied myocardium. Basic Res. Cardiol. 1996, 91 (Suppl. 2), 47-51. [CrossRef]

107. Eisenhofer, G.; Friberg, P.; Rundqvist, B.; Quyyumi, A.A.; Lambert, G.; Kaye, D.M.; Kopin, I.J.; Goldstein, D.S.; Esler, M.D. Cardiac sympathetic nerve function in congestive heart failure. Circulation 1996, 93, 1667-1676. [CrossRef] 
108. Bristow, M.R. Mechanism of action of beta-blocking agents in heart failure. Am. J. Cardiol. 1997, 80, 26L-40L. [CrossRef]

109. Nikolaev, V.O.; Moshkov, A.; Lyon, A.R.; Miragoli, M.; Novak, P.; Paur, H.; Lohse, M.J.; Korchev, Y.E.; Harding, S.E.; Gorelik, J. $\beta_{2}$-adrenergic receptor redistribution in heart failure changes cAMP compartmentation. Science 2010, 327, 1653-1657. [CrossRef] [PubMed]

110. Lymperopoulos, A.; Garcia, D.; Walklett, K. Pharmacogenetics of cardiac inotropy. Pharmacogenomics 2014, 15, $1807-1821$. [CrossRef]

111. Xiao, R.P.; Zhang, S.J.; Chakir, K.; Avdonin, P.; Zhu, W.; Bond, R.A.; Balke, C.W.; Lakatta, E.G.; Cheng, H. Enhanced Gignaling selectively negates $\beta_{2}$-adrenergic receptor (AR)-but not $\beta_{1}$-AR-mediated positive inotropic effect in myocytes from failing rat hearts. Circulation 2003, 108, 1633-1639. [CrossRef]

112. Zhu, W.; Petrashevskaya, N.; Ren, S.; Zhao, A.; Chakir, K.; Gao, E.; Chuprun, J.K.; Wang, Y.; Talan, M.; Dorn, G.W., 2nd; et al. $\mathrm{G}_{\mathrm{i}}$-biased $\beta_{2} \mathrm{AR}$ signaling links GRK2 upregulation to heart failure. Circ. Res. 2012, 110, 265-274. [CrossRef] [PubMed]

113. Salazar, N.C.; Vallejos, X.; Siryk, A.; Rengo, G.; Cannavo, A.; Liccardo, D.; De Lucia, C.; Gao, E.; Leosco, D.; Koch, W.J.; et al. GRK2 blockade with $\beta$ ARKct is essential for cardiac $\beta_{2}$-adrenergic receptor signaling towards increased contractility. Cell Commun. Signal. 2013, 11, 64. [CrossRef] [PubMed]

114. Ungerer, M.; Bohm, M.; Elce, J.S.; Erdmann, E.; Lohse, M.J. Altered expression of beta-adrenergic receptor kinase and beta 1-adrenergic receptors in the failing human heart. Circulation 1993, 87, 454-463. [CrossRef] [PubMed]

115. Lymperopoulos, A.; Rengo, G.; Funakoshi, H.; Eckhart, A.D.; Koch, W.J. Adrenal GRK2 upregulation mediates sympathetic overdrive in heart failure. Nat. Med. 2007, 13, 315-323. [CrossRef]

116. Du, X.J.; Autelitano, D.J.; Dilley, R.J.; Wang, B.; Dart, A.M.; Woodcock, E.A. $\beta_{2}$-adrenergic receptor overexpression exacerbates development of heart failure after aortic stenosis. Circulation 2000, 101, 71-77. [CrossRef]

117. Lee, G.J.; Yan, L.; Vatner, D.E.; Vatner, S.F. Mst1 inhibition rescues $\beta_{1}$-adrenergic cardiomyopathy by reducing myocyte necrosis and non-myocyte apoptosis rather than myocyte apoptosis. Basic Res. Cardiol. 2015, 110, 7. [CrossRef] [PubMed]

118. Wu, J.; Ge, Y.; Shi, Z.; Duan, X.; Wang, L.; Sun, X.; Zhang, K. Response inhibition in adolescent earthquake survivors with and without posttraumatic stress disorder: A combined behavioral and ERP study. Neurosci. Lett. 2010, 486, 117-121. [CrossRef] [PubMed]

119. Gorelik, J.; Wright, P.T.; Lyon, A.R.; Harding, S.E. Spatial control of the $\beta$ AR system in heart failure: The transverse tubule and beyond. Cardiovasc. Res. 2013, 98, 216-224. [CrossRef]

120. Siryk-Bathgate, A.; Dabul, S.; Lymperopoulos, A. Current and future G protein-coupled receptor signaling targets for heart failure therapy. Drug Des. Dev. Ther. 2013, 7, 1209-1222.

121. Xu, Q.; Dalic, A.; Fang, L.; Kiriazis, H.; Ritchie, R.H.; Sim, K.; Gao, X.M.; Drummond, G.; Sarwar, M.; Zhang, Y.Y.; et al. Myocardial oxidative stress contributes to transgenic $\beta_{2}$-adrenoceptor activation-induced cardiomyopathy and heart failure. Br. J. Pharm. 2011, 162, 1012-1028. [CrossRef]

122. Sheridan, D.J.; Autelitano, D.J.; Wang, B.; Percy, E.; Woodcock, E.A.; Du, X.J. $\beta_{2}$-adrenergic receptor overexpression driven by $\alpha$-MHC promoter is downregulated in hypertrophied and failing myocardium. Cardiovasc. Res. 2000, 47, 133-141. [CrossRef]

123. Du, X.J.; Gao, X.M.; Jennings, G.L.; Dart, A.M.; Woodcock, E.A. Preserved ventricular contractility in infarcted mouse heart overexpressing $\beta_{2}$-adrenergic receptors. Am. J. Physiol. Heart Circ. Physiol. 2000, 279, H2456-H2463. [CrossRef]

124. Paur, H.; Wright, P.T.; Sikkel, M.B.; Tranter, M.H.; Mansfield, C.; O'Gara, P.; Stuckey, D.J.; Nikolaev, V.O.; Diakonov, I.; Pannell, L.; et al. High levels of circulating epinephrine trigger apical cardiodepression in a $\beta_{2}$-adrenergic receptor $/ \mathrm{G}_{\mathrm{i}}$-dependent manner: A new model of Takotsubo cardiomyopathy. Circulation 2012, 126, 697-706. [CrossRef] [PubMed]

125. de Rooij, J.; Zwartkruis, F.J.; Verheijen, M.H.; Cool, R.H.; Nijman, S.M.; Wittinghofer, A.; Bos, J.L. Epac is a Rap1 guaninenucleotide-exchange factor directly activated by cyclic AMP. Nature 1998, 396, 474-477. [CrossRef]

126. Bouvet, M.; Blondeau, J.P.; Lezoualc'h, F. The Epac1 Protein: Pharmacological Modulators, Cardiac Signalosome and Pathophysiology. Cells 2019, 8, 1543. [CrossRef] [PubMed]

127. Fazal, L.; Laudette, M.; Paula-Gomes, S.; Pons, S.; Conte, C.; Tortosa, F.; Sicard, P.; Sainte-Marie, Y.; Bisserier, M.; Lairez, O.; et al. Multifunctional Mitochondrial Epac1 Controls Myocardial Cell Death. Circ. Res. 2017, 120, 645-657. [CrossRef] [PubMed]

128. Szanda, G.; Wisniewski, E.; Rajki, A.; Spat, A. Mitochondrial cAMP exerts positive feedback on mitochondrial Ca ${ }^{2+}$ uptake via the recruitment of Epac1. J. Cell Sci. 2018, 131.

129. Giorgi, C.; Marchi, S.; Pinton, P. The machineries, regulation and cellular functions of mitochondrial calcium. Nat. Rev. Mol. Cell Biol. 2018, 19, 713-730. [CrossRef] [PubMed]

130. Lezoualc'h, F.; Fazal, L.; Laudette, M.; Conte, C. Cyclic AMP Sensor EPAC Proteins and Their Role in Cardiovascular Function and Disease. Circ. Res. 2016, 118, 881-897. [CrossRef]

131. Okumura, S.; Fujita, T.; Cai, W.; Jin, M.; Namekata, I.; Mototani, Y.; Jin, H.; Ohnuki, Y.; Tsuneoka, Y.; Kurotani, R.; et al. Epac1dependent phospholamban phosphorylation mediates the cardiac response to stresses. J. Clin. Investig. 2014, 124, $2785-2801$. [CrossRef] [PubMed]

132. Laurent, A.C.; Bisserier, M.; Lucas, A.; Tortosa, F.; Roumieux, M.; De Regibus, A.; Swiader, A.; Sainte-Marie, Y.; Heymes, C.; Vindis, C.; et al. Exchange protein directly activated by cAMP 1 promotes autophagy during cardiomyocyte hypertrophy. Cardiovasc. Res. 2015, 105, 55-64. [CrossRef] [PubMed] 
133. Laudette, M.; Coluccia, A.; Sainte-Marie, Y.; Solari, A.; Fazal, L.; Sicard, P.; Silvestri, R.; Mialet-Perez, J.; Pons, S.; Ghaleh, B.; et al. Identification of a pharmacological inhibitor of Epac1 that protects the heart against acute and chronic models of cardiac stress. Cardiovasc. Res. 2019, 115, 1766-1777. [CrossRef]

134. Wang, J.; Hanada, K.; Staus, D.P.; Makara, M.A.; Dahal, G.R.; Chen, Q.; Ahles, A.; Engelhardt, S.; Rockman, H.A. Galphai is required for carvedilol-induced $\beta_{1}$ adrenergic receptor $\beta$-arrestin biased signaling. Nat. Commun. 2017, 8, 1706. [CrossRef]

135. Wang, Q.; Wang, Y.; West, T.M.; Liu, Y.; Reddy, G.R.; Barbagallo, F.; Xu, B.; Shi, Q.; Deng, B.; Wei, W.; et al. Carvedilol induces biased $\beta_{1}$ adrenergic receptor-Nitric oxide synthase 3-cyclic guanylyl monophosphate signaling to promote cardiac contractility. Cardiovasc. Res. 2020. [CrossRef]

136. Littmann, T.; Gottle, M.; Reinartz, M.T.; Kalble, S.; Wainer, I.W.; Ozawa, T.; Seifert, R. Recruitment of $\beta$-arrestin 1 and 2 to the $\beta_{2}$-adrenoceptor: Analysis of 65 ligands. J. Pharm. Exp. 2015, 355, 183-190. [CrossRef] [PubMed]

137. O’Hayre, M.; Eichel, K.; Avino, S.; Zhao, X.; Steffen, D.J.; Feng, X.; Kawakami, K.; Aoki, J.; Messer, K.; Sunahara, R.; et al. Genetic evidence that $\beta$-arrestins are dispensable for the initiation of $\beta_{2}$-adrenergic receptor signaling to ERK. Sci. Signal. 2017, 10. [CrossRef]

138. Desimine, V.L.; McCrink, K.A.; Parker, B.M.; Wertz, S.L.; Maning, J.; Lymperopoulos, A. Biased Agonism/Antagonism of Cardiovascular GPCRs for Heart Failure Therapy. Int. Rev. Cell Mol. Biol. 2018, 339, 41-61. [PubMed]

139. Yang, H.Q.; Wang, L.P.; Gong, Y.Y.; Fan, X.X.; Zhu, S.Y.; Wang, X.T.; Wang, Y.P.; Li, L.L.; Xing, X.; Liu, X.X.; et al. $\beta_{2}$-Adrenergic Stimulation Compartmentalizes $\beta_{1}$ Signaling Into Nanoscale Local Domains by Targeting the C-Terminus of $\beta_{1}$-Adrenoceptors. Circ. Res. 2019, 124, 1350-1359. [CrossRef] [PubMed]

140. Grisan, F.; Burdyga, A.; Iannucci, L.F.; Surdo, N.C.; Pozzan, T.; Di Benedetto, G.; Lefkimmiatis, K. Studying $\beta_{1}$ and $\beta_{2}$ adrenergic receptor signals in cardiac cells using FRET-based sensors. Prog. Biophys. Mol. Biol. 2020, 154, 30-38. [CrossRef] [PubMed]

141. Delaunay, M.; Osman, H.; Kaiser, S.; Diviani, D. The Role of Cyclic AMP Signaling in Cardiac Fibrosis. Cells 2019, 9, 69. [CrossRef]

142. Turner, N.A.; Porter, K.E.; Smith, W.H.; White, H.L.; Ball, S.G.; Balmforth, A.J. Chronic $\beta_{2}$-adrenergic receptor stimulation increases proliferation of human cardiac fibroblasts via an autocrine mechanism. Cardiovasc. Res. 2003, 57, 784-792. [CrossRef]

143. Chen, C.; Du, J.; Feng, W.; Song, Y.; Lu, Z.; Xu, M.; Li, Z.; Zhang, Y. $\beta$-Adrenergic receptors stimulate interleukin-6 production through Epac-dependent activation of PKCdelta/p38 MAPK signalling in neonatal mouse cardiac fibroblasts. Br. J. Pharm. 2012, 166, 676-688. [CrossRef]

144. Travers, J.G.; Kamal, F.A.; Valiente-Alandi, I.; Nieman, M.L.; Sargent, M.A.; Lorenz, J.N.; Molkentin, J.D.; Blaxall, B.C. Pharmacological and Activated Fibroblast Targeting of G $\beta \gamma$-GRK2 After Myocardial Ischemia Attenuates Heart Failure Progression. J. Am. Coll. Cardiol. 2017, 70, 958-971. [CrossRef]

145. Yin, F.; Wang, Y.Y.; Du, J.H.; Li, C.; Lu, Z.Z.; Han, C.; Zhang, Y.Y. Noncanonical cAMP pathway and p38 MAPK mediate $\beta_{2}$-adrenergic receptor-induced IL-6 production in neonatal mouse cardiac fibroblasts. J. Mol. Cell Cardiol. 2006, 40, 384-393. [CrossRef]

146. Kiriazis, H.; Wang, K.; Xu, Q.; Gao, X.M.; Ming, Z.; Su, Y.; Moore, X.L.; Lambert, G.; Gibbs, M.E.; Dart, A.M.; et al. Knockout of $\beta_{1}$ and $\beta_{2}$-adrenoceptors attenuates pressure overload-induced cardiac hypertrophy and fibrosis. Br. J. Pharm. 2008, 153, 684-692. [CrossRef] [PubMed]

147. Insel, P.A.; Murray, F.; Yokoyama, U.; Romano, S.; Yun, H.; Brown, L.; Snead, A.; Lu, D.; Aroonsakool, N. cAMP and Epac in the regulation of tissue fibrosis. Br. J. Pharm. 2012, 166, 447-456. [CrossRef] [PubMed]

148. Pollard, C.M.; Desimine, V.L.; Wertz, S.L.; Perez, A.; Parker, B.M.; Maning, J.; McCrink, K.A.; Shehadeh, L.A.; Lymperopoulos, A. Deletion of Osteopontin Enhances $\beta_{2}$-Adrenergic Receptor-Dependent Anti-Fibrotic Signaling in Cardiomyocytes. Int. J. Mol. Sci. 2019, 20, 1396. [CrossRef] [PubMed]

149. Woodcock, E.A.; Du, X.J.; Reichelt, M.E.; Graham, R.M. Cardiac $\alpha_{1}$-adrenergic drive in pathological remodelling. Cardiovasc. Res. 2008, 77, 452-462. [CrossRef]

150. Jensen, B.C.; O'Connell, T.D.; Simpson, P.C. Alpha-1-adrenergic receptors in heart failure: The adaptive arm of the cardiac response to chronic catecholamine stimulation. J. Cardiovasc. Pharm. 2014, 63, 291-301. [CrossRef]

151. O'Connell, T.D.; Swigart, P.M.; Rodrigo, M.C.; Ishizaka, S.; Joho, S.; Turnbull, L.; Tecott, L.H.; Baker, A.J.; Foster, E.; Grossman, W.; et al. $\alpha_{1}$-adrenergic receptors prevent a maladaptive cardiac response to pressure overload. J. Clin. Investig. 2006, 116, 1005-1015. [CrossRef]

152. Wang, B.H.; Du, X.J.; Autelitano, D.J.; Milano, C.A.; Woodcock, E.A. Adverse effects of constitutively active $\alpha_{1 B}$-adrenergic receptors after pressure overload in mouse hearts. Am. J. Physiol. Heart Circ. Physiol. 2000, 279, H1079-H1086. [CrossRef]

153. Huang, Y.; Wright, C.D.; Merkwan, C.L.; Baye, N.L.; Liang, Q.; Simpson, P.C.; O'Connell, T.D. An alpha1A-adrenergic-extracellular signal-regulated kinase survival signaling pathway in cardiac myocytes. Circulation 2007, 115, 763-772. [CrossRef]

154. Myagmar, B.E.; Ismaili, T.; Swigart, P.M.; Raghunathan, A.; Baker, A.J.; Sahdeo, S.; Blevitt, J.M.; Milla, M.E.; Simpson, P.C. Coupling to $\mathrm{Gq}$ Signaling Is Required for Cardioprotection by an Alpha-1A-Adrenergic Receptor Agonist. Circ. Res. 2019, 125, 699-706. [CrossRef]

155. Shi, T.; Papay, R.S.; Perez, D.M. $\alpha_{1 \mathrm{~A}}$-Adrenergic receptor prevents cardiac ischemic damage through PKCdelta/GLUT1/4mediated glucose uptake. J. Recept. Signal Transduct. Res. 2016, 36, 261-270. [CrossRef]

156. Lin, F.; Owens, W.A.; Chen, S.; Stevens, M.E.; Kesteven, S.; Arthur, J.F.; Woodcock, E.A.; Feneley, M.P.; Graham, R.M. Targeted $\alpha_{1 \mathrm{~A}}$-adrenergic receptor overexpression induces enhanced cardiac contractility but not hypertrophy. Circ. Res. 2001, 89, 343-350. [CrossRef] [PubMed] 
157. Beak, J.; Huang, W.; Parker, J.S.; Hicks, S.T.; Patterson, C.; Simpson, P.C.; Ma, A.; Jin, J.; Jensen, B.C. An Oral Selective Alpha-1A Adrenergic Receptor Agonist Prevents Doxorubicin Cardiotoxicity. JACC Basic Transl. Sci. 2017, 2, 39-53. [CrossRef] [PubMed]

158. Montgomery, M.D.; Chan, T.; Swigart, P.M.; Myagmar, B.E.; Dash, R.; Simpson, P.C. An Alpha-1A Adrenergic Receptor Agonist Prevents Acute Doxorubicin Cardiomyopathy in Male Mice. PLoS ONE 2017, 12, e0168409. [CrossRef] [PubMed]

159. Jensen, B.C.; Swigart, P.M.; De Marco, T.; Hoopes, C.; Simpson, P.C. $\alpha 1$-Adrenergic receptor subtypes in nonfailing and failing human myocardium. Circ. Heart Fail. 2009, 2, 654-663. [CrossRef]

160. Janssen, P.M.L.; Canan, B.D.; Kilic, A.; Whitson, B.A.; Baker, A.J. Human Myocardium Has a Robust $\alpha 1$ A-Subtype Adrenergic Receptor Inotropic Response. J. Cardiovasc. Pharm. 2018, 72, 136-142. [CrossRef]

161. Yu, Z.Y.; Tan, J.C.; McMahon, A.C.; Iismaa, S.E.; Xiao, X.H.; Kesteven, S.H.; Reichelt, M.E.; Mohl, M.C.; Smith, N.J.; Fatkin, D.; et al. RhoA/ROCK signaling and pleiotropic $\alpha_{1 \mathrm{~A}}$-adrenergic receptor regulation of cardiac contractility. PLoS ONE 2014, 9, e99024. [CrossRef]

162. Mohl, M.C.; Iismaa, S.E.; Xiao, X.H.; Friedrich, O.; Wagner, S.; Nikolova-Krstevski, V.; Wu, J.; Yu, Z.Y.; Feneley, M.; Fatkin, D.; et al. Regulation of murine cardiac contractility by activation of $\alpha_{1 \mathrm{~A}}$-adrenergic receptor-operated $\mathrm{Ca}^{2+}$ entry. Cardiovasc. Res. 2011, 91, 310-319. [CrossRef]

163. Hein, L.; Altman, J.D.; Kobilka, B.K. Two functionally distinct $\alpha 2$-adrenergic receptors regulate sympathetic neurotransmission. Nature 1999, 402, 181-184. [CrossRef]

164. Brede, M.; Wiesmann, F.; Jahns, R.; Hadamek, K.; Arnolt, C.; Neubauer, S.; Lohse, M.J.; Hein, L. Feedback inhibition of catecholamine release by two different $\alpha_{2}$-adrenoceptor subtypes prevents progression of heart failure. Circulation 2002, 106, 2491-2496. [CrossRef] [PubMed]

165. Brede, M.; Nagy, G.; Philipp, M.; Sorensen, J.B.; Lohse, M.J.; Hein, L. Differential control of adrenal and sympathetic catecholamine release by $\alpha_{2}$-adrenoceptor subtypes. Mol. Endocrinol. 2003, 17, 1640-1646. [CrossRef] [PubMed]

166. Brede, M.; Philipp, M.; Knaus, A.; Muthig, V.; Hein, L. $\alpha_{2}$-adrenergic receptor subtypes-novel functions uncovered in genetargeted mouse models. Biol. Cell 2004, 96, 343-348. [CrossRef] [PubMed]

167. Lymperopoulos, A.; Rengo, G.; Gao, E.; Ebert, S.N.; Dorn, G.W., 2nd; Koch, W.J. Reduction of sympathetic activity via adrenaltargeted GRK2 gene deletion attenuates heart failure progression and improves cardiac function after myocardial infarction. $J$. Biol. Chem. 2010, 285, 16378-16386. [CrossRef]

168. Jafferjee, M.; Reyes Valero, T.; Marrero, C.; McCrink, K.A.; Brill, A.; Lymperopoulos, A. GRK2 Up-Regulation Creates a Positive Feedback Loop for Catecholamine Production in Chromaffin Cells. Mol. Endocrinol. 2016, 30, 372-381. [CrossRef] [PubMed]

169. Schneider, J.; Lother, A.; Hein, L.; Gilsbach, R. Chronic cardiac pressure overload induces adrenal medulla hypertrophy and increased catecholamine synthesis. Basic Res. Cardiol. 2011, 106, 591-602. [CrossRef]

170. Nguyen, K.; Kassimatis, T.; Lymperopoulos, A. Impaired desensitization of a human polymorphic $\alpha_{2 B}$-adrenergic receptor variant enhances its sympatho-inhibitory activity in chromaffin cells. Cell Commun. Signal. 2011, 9, 5. [CrossRef]

171. Small, K.M.; Wagoner, L.E.; Levin, A.M.; Kardia, S.L.; Liggett, S.B. Synergistic polymorphisms of beta1- and alpha2C-adrenergic receptors and the risk of congestive heart failure. N. Engl. J. Med. 2002, 347, 1135-1142. [CrossRef] [PubMed]

172. O'Connor, C.M.; Fiuzat, M.; Carson, P.E.; Anand, I.S.; Plehn, J.F.; Gottlieb, S.S.; Silver, M.A.; Lindenfeld, J.; Miller, A.B.; White, M.; et al. Combinatorial pharmacogenetic interactions of bucindolol and $\beta_{1}, \alpha_{2}$ adrenergic receptor polymorphisms. PLoS ONE 2012, 7, e44324. [CrossRef]

173. Lymperopoulos, A.; Aukszi, B. Angiotensin receptor blocker drugs and inhibition of adrenal $\beta$-arrestin-1-dependent aldosterone production: Implications for heart failure therapy. World J. Cardiol. 2017, 9, 200-206. [CrossRef]

174. Luttrell, L.M.; Gesty-Palmer, D. Beyond desensitization: Physiological relevance of arrestin-dependent signaling. Pharm. Rev. 2010, 62, 305-330. [CrossRef]

175. Lymperopoulos, A.; Rengo, G.; Zincarelli, C.; Kim, J.; Koch, W.J. Adrenal $\beta$-arrestin 1 inhibition in vivo attenuates post-myocardial infarction progression to heart failure and adverse remodeling via reduction of circulating aldosterone levels. J. Am. Coll. Cardiol. 2011, 57, 356-365. [CrossRef] [PubMed]

176. Lymperopoulos, A.; Rengo, G.; Zincarelli, C.; Kim, J.; Soltys, S.; Koch, W.J. An adrenal $\beta$-arrestin 1-mediated signaling pathway underlies angiotensin II-induced aldosterone production in vitro and in vivo. Proc. Natl. Acad. Sci. USA 2009, 106, 5825-5830. [CrossRef] [PubMed]

177. Pollard, C.M.; Ghandour, J.; Cora, N.; Perez, A.; Parker, B.M.; Desimine, V.L.; Wertz, S.L.; Pereyra, J.M.; Ferraino, K.E.; Patel, J.J.; et al. GRK2-Mediated Crosstalk between $\beta$-Adrenergic and Angiotensin II Receptors Enhances Adrenocortical Aldosterone Production In Vitro and In Vivo. Int. J. Mol. Sci. 2020, 21, 574. [CrossRef] [PubMed]

178. Cora, N.; Ghandour, J.; Pollard, C.M.; Desimine, V.L.; Ferraino, K.E.; Pereyra, J.M.; Valiente, R.; Lymperopoulos, A. Nicotineinduced adrenal $\beta$-arrestin1 upregulation mediates tobacco-related hyperaldosteronism leading to cardiac dysfunction. World J. Cardiol. 2020, 12, 192-202. [CrossRef] [PubMed]

179. Ferraino, K.E.; Cora, N.; Pollard, C.M.; Sizova, A.; Maning, J.; Lymperopoulos, A. Adrenal angiotensin II type 1 receptor biased signaling: The case for "biased" inverse agonism for effective aldosterone suppression. Cell Signal. 2021, 82, 109967. [CrossRef] [PubMed]

180. Maning, J.; McCrink, K.A.; Pollard, C.M.; Desimine, V.L.; Ghandour, J.; Perez, A.; Cora, N.; Ferraino, K.E.; Parker, B.M.; Brill, A.R.; et al. Antagonistic Roles of GRK2 and GRK5 in Cardiac Aldosterone Signaling Reveal GRK5-Mediated Cardioprotection via Mineralocorticoid Receptor Inhibition. Int. J. Mol. Sci. 2020, 21, 2868. [CrossRef] [PubMed] 
181. Sato, P.Y.; Chuprun, J.K.; Schwartz, M.; Koch, W.J. The evolving impact of g protein-coupled receptor kinases in cardiac health and disease. Physiol. Rev. 2015, 95, 377-404. [CrossRef]

182. Marzano, F.; Rapacciuolo, A.; Ferrara, N.; Rengo, G.; Koch, W.J.; Cannavo, A. Targeting GRK5 for Treating Chronic Degenerative Diseases. Int. J. Mol. Sci. 2021, 22, 1920. [CrossRef] [PubMed]

183. Coleman, R.C.; Eguchi, A.; Lieu, M.; Roy, R.; Barr, E.W.; Ibetti, J.; Lucchese, A.M.; Peluzzo, A.M.; Gresham, K.; Chuprun, J.K.; et al. A peptide of the $\mathrm{N}$ terminus of GRK5 attenuates pressure-overload hypertrophy and heart failure. Sci. Signal. 2021, 14. [CrossRef]

184. Liggett, S.B.; Cresci, S.; Kelly, R.J.; Syed, F.M.; Matkovich, S.J.; Hahn, H.S.; Diwan, A.; Martini, J.S.; Sparks, L.; Parekh, R.R., 2nd; et al A GRK5 polymorphism that inhibits $\beta$-adrenergic receptor signaling is protective in heart failure. Nat. Med. 2008, 14, 510-517. [CrossRef]

185. Wu, J.H.; Zhang, L.; Fanaroff, A.C.; Cai, X.; Sharma, K.C.; Brian, L.; Exum, S.T.; Shenoy, S.K.; Peppel, K.; Freedman, N.J. G protein-coupled receptor kinase- 5 attenuates atherosclerosis by regulating receptor tyrosine kinases and 7-transmembrane receptors. Arterioscler. Thromb. Vasc. Biol. 2012, 32, 308-316. [CrossRef]

186. Monto, F.; Oliver, E.; Vicente, D.; Rueda, J.; Aguero, J.; Almenar, L.; Ivorra, M.D.; Barettino, D.; D’Ocon, P. Different expression of adrenoceptors and GRKs in the human myocardium depends on heart failure etiology and correlates to clinical variables. Am. J. Physiol. Heart Circ. Physiol. 2012, 303, H368-H376. [CrossRef]

187. Sorriento, D.; Ciccarelli, M.; Santulli, G.; Campanile, A.; Altobelli, G.G.; Cimini, V.; Galasso, G.; Astone, D.; Piscione, F.; Pastore, L.; et al. The G-protein-coupled receptor kinase 5 inhibits NFkB transcriptional activity by inducing nuclear accumulation of IkB $\alpha$. Proc. Natl. Acad. Sci. USA 2008, 105, 17818-17823. [CrossRef]

188. de Lucia, C.; Grisanti, L.A.; Borghetti, G.; Piedepalumbo, M.; Ibetti, J.; Maria Lucchese, A.; Barr, E.W.; Roy, R.; Dedo Okyere, A.; Christine Murphy, H.; et al. GRK5 contributes to impaired cardiac function and immune cell recruitment in post-ischemic heart failure. Cardiovasc. Res. 2021. [CrossRef]

189. Eguchi, A.; Coleman, R.; Gresham, K.; Gao, E.; Ibetti, J.; Chuprun, J.K.; Koch, W.J. GRK5 is a regulator of fibroblast activation and cardiac fibrosis. Proc. Natl. Acad. Sci. USA 2021, 118. [CrossRef] [PubMed]

190. Beyett, T.S.; Fraley, A.E.; Labudde, E.; Patra, D.; Coleman, R.C.; Eguchi, A.; Glukhova, A.; Chen, Q.; Williams, R.M.; Koch, W.J.; et al. Perturbation of the interactions of calmodulin with GRK5 using a natural product chemical probe. Proc. Natl. Acad. Sci. USA 2019, 116, 15895-15900. [CrossRef] [PubMed]

191. Pabbidi, M.R.; Ji, X.; Maxwell, J.T.; Mignery, G.A.; Samarel, A.M.; Lipsius, S.L. Inhibition of cAMP-Dependent PKA Activates $\beta_{2}$-Adrenergic Receptor Stimulation of Cytosolic Phospholipase A2 via Raf-1/MEK/ERK and IP3-Dependent Ca ${ }^{2+}$ Signaling in Atrial Myocytes. PLoS ONE 2016, 11, e0168505. [CrossRef]

192. Hori, Y.; Touei, D.; Saitoh, R.; Yamagishi, M.; Kanai, K.; Hoshi, F.; Itoh, N. The Aldosterone Receptor Antagonist Eplerenone Inhibits Isoproterenol-Induced Collagen-I and 11ß-HSD1 Expression in Rat Cardiac Fibroblasts and the Left Ventricle. Biol. Pharm. Bull. 2017, 40, 1716-1723. [CrossRef] [PubMed]

193. Grossmann, C.; Wuttke, M.; Ruhs, S.; Seiferth, A.; Mildenberger, S.; Rabe, S.; Schwerdt, G.; Gekle, M. Mineralocorticoid receptor inhibits CREB signaling by calcineurin activation. FASEB J. 2010, 24, 2010-2019. [CrossRef]

194. Karkoulias, G.; McCrink, K.A.; Maning, J.; Pollard, C.M.; Desimine, V.L.; Patsouras, N.; Psallidopoulos, M.; Taraviras, S.; Lymperopoulos, A.; Flordellis, C. Sustained GRK2-dependent CREB activation is essential for $\alpha 2$-adrenergic receptor-induced PC12 neuronal differentiation. Cell Signal. 2020, 66, 109446. [CrossRef] [PubMed]

195. Lister, K.; Autelitano, D.J.; Jenkins, A.; Hannan, R.D.; Sheppard, K.E. Cross talk between corticosteroids and alpha-adrenergic signalling augments cardiomyocyte hypertrophy: A possible role for SGK1. Cardiovasc. Res. 2006, 70, 555-565. [CrossRef] [PubMed] 